Diagenesis in Oolitic Limestones of Morrow

(Early Pennsylvanian) Age

in Northwestern Arkansas

and Adjacent Oklahoma

GEOLOGIGAL SURVEY PROFESSIONAL PAPER 594-H 

Diagenesis in Oolitic

Limestones of Morrow

(Early Pennsylvanian) Age

in Northwestern Arkansas

and Adjacent Oklahoma

By LLOYD G. HENBEST

SHORTER CONTRIBUTIONS TO GENERAL GEOLOGY

GEOLOGICAL SURVEY PROFESIONAL PAPER 594-H

The diagenetic history in marine sandy

limestones; the time relations, environment,

and causes of diagenetic interactions between

calcite, aragonite, and quartz are indicated

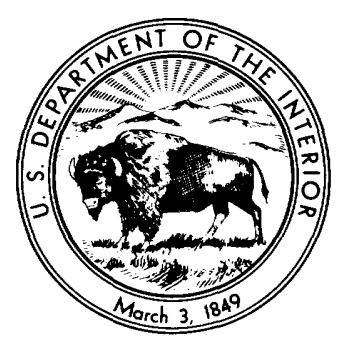

UNITED STATES GOVERNMENT PRINTING OFFICE, WASHINGTON : 1968 


\section{UNITED STATES DEPARTMENT OF THE INTERIOR \\ STEWART L. UDALL, Secretary \\ GEOLOGICAL SURVEY \\ William T. Pecora, Director}




\section{CONTENTS}

Abstract

Introduction

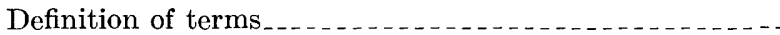

Acknowledgments

Stratigraphic position and lithology

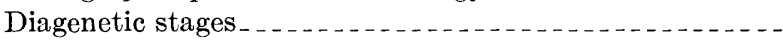

Diagenetic record in Bloyd Formation at Gaylor Ferry,

Okla.

Lithologic setting

Diagenetic stage 1 , compacti

Diagenetic stage 2, quartz and carbonate exchange

Diagenetic stage 2 in Prairie Grove Member of Hale

Formation, Arkansas.
Page

H1 Diagenetic stages 2 and 3 in Kessler Limestone Member

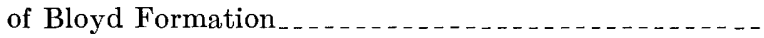
Source and transfer of quartz in the overgrowths......

Geologic environment_.......................... Provenance, volcanic ash versus solution etching.-.-

Etch pits and the problem of quartz solution and transfer....................................

Date of diagenetic stages 1 and $2 \ldots \ldots \ldots$ Modified metal coating for resolution of minute

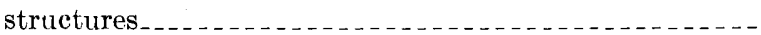

Collection data

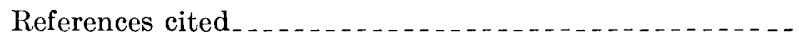

Page

$\mathrm{H} 14$

15

15

16

17

19

19

20

21

\section{ILLUSTRATIONS}

Figure 1. Composite section of the type Morrow Series and adjacent rocks in Washington County, Ark

2. Ooliths with granular calcite in nuclei

3. Microstylolitic interpenetration of ooliths of diagenetic stage 1 and quartz overgrowths of diagenetic stage 2

4. Characteristic features of oolitic limestone in Bloyd Formation at Gaylor Ferry, Okla _.............

5. Curved microstylolitic column incorporated by a subsequent quartz overgrowth

6. Closed system of quartz-calcite exchange within an oolith

7. Ooliths with secondarily enlarged nuclei, illustrating a closed system of quartz-calcite exchange ..........

8. Microstylolite of diagenetic stage 1 incorporated by quartz overgrowth of stage 2

9. Quartz overgrowth with spheric terminations_._.

10. Example of calcitic fossil, an echinoderm plate, acting as a barrier to growth of secondary quartz

11. Example of combined etching and secondary enlargement of quartz sand grains

12-13. Serial views of quartz seed grains showing solution-etch figures and secondary crystal growth

14. Etch pattern in quartz grain from matrix

15. Contact between an algal-foraminiferal colony, Ottonosia sp., and its nucleus, an exotic cobble of oolitic limestone..................

16. Exotic cobble of oolitic limestone from basal conglomerate of Kessler Limestone Member of Bloyd Formation showing diagenetic stages 2 and 3

Page 

SHORTER CONTRIBUTIONS TO GENERAL GEOLOGY

\title{
DIAGENESIS IN OOLITIG LIMESTONES OF MORROW (EARLY PENNSYLVANIAN) AGE IN NORTHWESTERN ARKANSAS AND ADJAGENT OKLAHOMA
}

\author{
By Lloyd G. Henbest
}

\begin{abstract}
Major diagenetic events are recorded with unusual clarity in oolites within the Morrow Series. Three distinct diagenetic stages are recognizable. Stage 1 consisted of compaction syndromes. Wherever the ooliths were supported by contact with each other, they interpenetrated by microstylolitic action. The microstylolites are restricted to oolith contacts. During interpenetration, some ooliths rotated or moved as individual bodies, showing that compaction antedated the final cementation and lithification of the sediment. Diagenetic stage 2 consisted of silica-carbonate exchange. After compaction, quartz sand nuclei of ooliths were enlarged with euhedral overgrowths of quartz at the expense of the aragonitic component of the ooliths. Moreover, the quartz sand grains in the matrix that touched an oolith were secondarily enlarged only at the contact with the oolith, but the same grains were solution-etched at interfaces with the matrix. The solution-etch pits are filled with calcite and do not reflect the crystal structure of the quartz grain. All quartz sand grains in the matrix near ooliths that contain quartz sand nuclei are etched to some degree. Quartz overgrowths occurred only within the aragonitic concretions of ooliths. No quartz overgrowths extended from inside an oolith into the matrix, and very few penetrated microstylolites. No overgrowths originated or grew in the matrix. The microstylolites antedated the quartz overgrowths.

An environment of unusual temperatures, great sedimentary load, and external sources of solutions is contraindicated. Though the presence of ash has been suspected by some geologists, ash has not yet been positively identified in these rocks. Etching of quartz sand in the matrix, and not ash, is indicated as the source of the secondary quartz in the overgrowths. The quartz and carbonate exchange in the Morrow oolites occurred in a closed system generally having a radius of only $0.01-1.5 \mathrm{~mm}$ in an environment of virtually static water and unimpeded even by cementation of interstitial space. The solution and transfer of the quartz seem to have been caused by the difference in reactivity of calcite and aragonite and the alkalinity of calcite and aragonite as weak salts. The $\mathrm{pH}$ differential from either or both sources is far too small to cause silica solution at room temperature in the time limits of a laboratory experiment. Diagenetic stage 3 consisted of selective replacement of algalforaminiferal nodules at some places in the Kessler Limestone Member of the Bloyd Formation by spongy limonitic microcrystalline silica. The date of replacement is unknown except that it is later than stage 2. Indefinite evidence suggests that diagenetic stages 1 and 2 occurred in Pennsylvanian time or not later than Mesozoic time.
\end{abstract}

\section{INTRODUCTION}

A diagenetic record of unusual clarity is preserved in oolitic limestone in the Morrow Series of northwestern Arkansas and the adjacent part of Oklahoma. In these oolitic limestones the time relation of the more important diagenetic events and the environmental history of the rocks since burial are determinable in exceptional detail. This makes it possible to isolate relevant from irrelevant factors in attempts to recognize the nature and causes of the diagenetic reconstructions.

The oolitic limestones in the Morrow are marine and are variously sandy. The diagenetic modifications represent some of the most common and important kinds of modifications in marine limestones and sandstones. For this reason the Morrow oolites serve as a reference for interpreting other, but more obscure, diagenetic records, particularly for reconstructing the history and behavior of marine aquifers and reservoirs of oil and gas.

This paper does not attempt to delineate the entire history of changes in the oolites from deposition to final exhumation and weathering. The diagenetic stages here described, however, represent the most important changes that occurred.

Secondary enlargement of quartz sand nuclei of oolite grains in the Morrow rocks (USGS f771) was first described by Henbest (1945). (See also Pettijohn, 1949, p. 499, and Kholodov, 1960, p. 56-58). At that time, the Prairie Grove Member of the Hale Formation had not been differentiated from the Brentwood Limestone Member of the Bloyd Formation, and the oolite bed was classed as a part of the Brentwood. When that example of secondary enlargement of the nuclei was found, it was thought to be unusual. Observations since that time have suggested that such secondary overgrowths may be a rather common feature of oolitic limestones of Paleozoic age. Later studies of Morrow rocks revealed other occurrences that added much new information (Henbest, 1965). 


\section{DEFINITION OF TERMS}

In this paper, the term "matrix" is used in its accustomed sense as the medium in which the objects of discussion (the ooliths) are embedded. In the original unlithified deposits of the Morrow oolites, the matrix ranged from calcareous silt to an unsorted aggregate of biogenic detritus and quartz sand. In many places, the aggregate contains shell particles larger than the ooliths, but this does not conflict with the normal use of the term "matrix."

Inasmuch as the nomenclature of ooidal grains is not uniform, the usage in this paper is defined. The terms "oolites" ("true oolites" of some authors), "oolitic limestone," or simply "oolite" (in the sense of oolitic limestone or formation) pertain to the kind of ooidal grain that is composed of a nucleus and a concentrically layered deposit of fibrous, radially arranged crystals of aragonite. The shape is generally spheric to subspheric. By generally accepted definition, the maximum size is $2.0 \mathrm{~mm}$. This kind of ooidal grain is called an oolith (DeFord and Waldschmidt, 1946) in this paper. The larger grains with such structures are called pisolites. Individual grains should be called pisoliths. The nucleus of Morrow ooliths consists, with decreasing frequency, of a grain of sand, a shell fragment, a foraminifer shell, or a molluscan protoconch, but minute carbonate fecal(?) pellets also occur as nuclei.

The proposal by DeFord and Waldschmidt (1946) for calling an individual oolite grain an "oolith" deserves a larger following. Other kinds of ooidal grains ("pseudo-oolites" of some authors) resemble ooliths externally and are common in Paleozoic and younger limestones. Such are the principal constituents in some so-called oolitic limestones. The most common kind of pseudo-ooliths are algal ooids which resemble true ooliths in size and external appearance but differ internally by consisting of incrustations of sand or other grains by girvanellid algae. An informal class term for oolitic and pseudo-oolitic grains is needed. The terms "ooid" and "ooidal" are the natural choice and should remain available in that sense.

As used in this report, the term "diagenesis" pertains to the modification of the texture, structure, and mineral composition of a sediment from its deposition and burial to its ultimate exhumation and weathering. (See Pettijohn, 1949, p. 476.) Modification of lower grade than metamorphism is understood.

\section{ACKNOWLEDGMENTS}

Lloyd C. Pray, Marathon Oil Co., Littleton, Colo., and Brian J. Skinner and James F. Mello, U.S. Geological Survey, reviewed the manuscript. Discussions of the problems with Hugh D. Miser, U.S. Geological Survey, were characteristically stimulating and clarifying. Brian J. Skinner searched the thin sections from USGS collection f886 for possible residual products of ash decay. Edwin Roedder studied the overgrowths for organic content. Edward J. Dwornik vapor-coated the microscopic quartz crystals and the naturally etched quartz grains from insoluble residues with silver or with chromium. John O. Hutchison prepared the thin sections. Robert H. McKinney printed my photographic negatives.

\section{STRATIGRAPHIC POSITION AND LITHOLOGY}

The geology of the Morrow rocks and references to earlier publications are presented in three previous papers (Henbest, 1953; 1962a, b). Only the geologic data that pertain to diagenesis are repeated here.

The oolitic limestone beds studied are members of the Hale and the Bloyd Formations, which compose the provincial Morrow Series of Early Pennsylvanian age in the Ozark Plateaus of Arkansas and Oklahoma (fig. 1). The type area of the series is in Washington County, Ark. In decreasing order of volume, the rocks of the type area are composed of shaly marine siltstone and claystone, limestone, calcareous sandstone, quartz pebble conglomerate, local lenses of basal and channel conglomerate, and a thin terrestrial unit that includes a coal bed. The relative proportions of these constituents change westward into more calcareous facies in Oklahoma, but the Hale and Bloyd Formations continue to be recognizable.

Local oolitic beds or phases are widely distributed through the marine limestones of the Morrow. Though oolites are more characteristic of the Kessler Limestone Member of the Bloyd Formation than of any other unit, their distribution is not uniform even in the Kessler.

Locally, the Morrow limestones contain algal ooids that have sand grains for nuclei. The ooids resemble ooliths in size and external appearance and may be mistaken for true ooliths. The algal ooids are minute colonies of Girvanella-like calcareous algae which incrusted grains of the same kinds of detritus as those that form the nuclei of ooliths. Microscopically, these algal ooids resemble Osagia Twenhofel, 1919, but generally, or perhaps always, lack associated sedentary Foraminifera. The algal ooids are commonly associated with ooliths and seem to have been formed in related environments.

In some places, ooliths, or both ooliths and algal ooids, are sufficiently abundant to characterize a Morrow limestone unit, but usually such concentrations are discontinuous geographically and stratigraphically. In all occurrences so far studied, the ooliths and algal ooids 


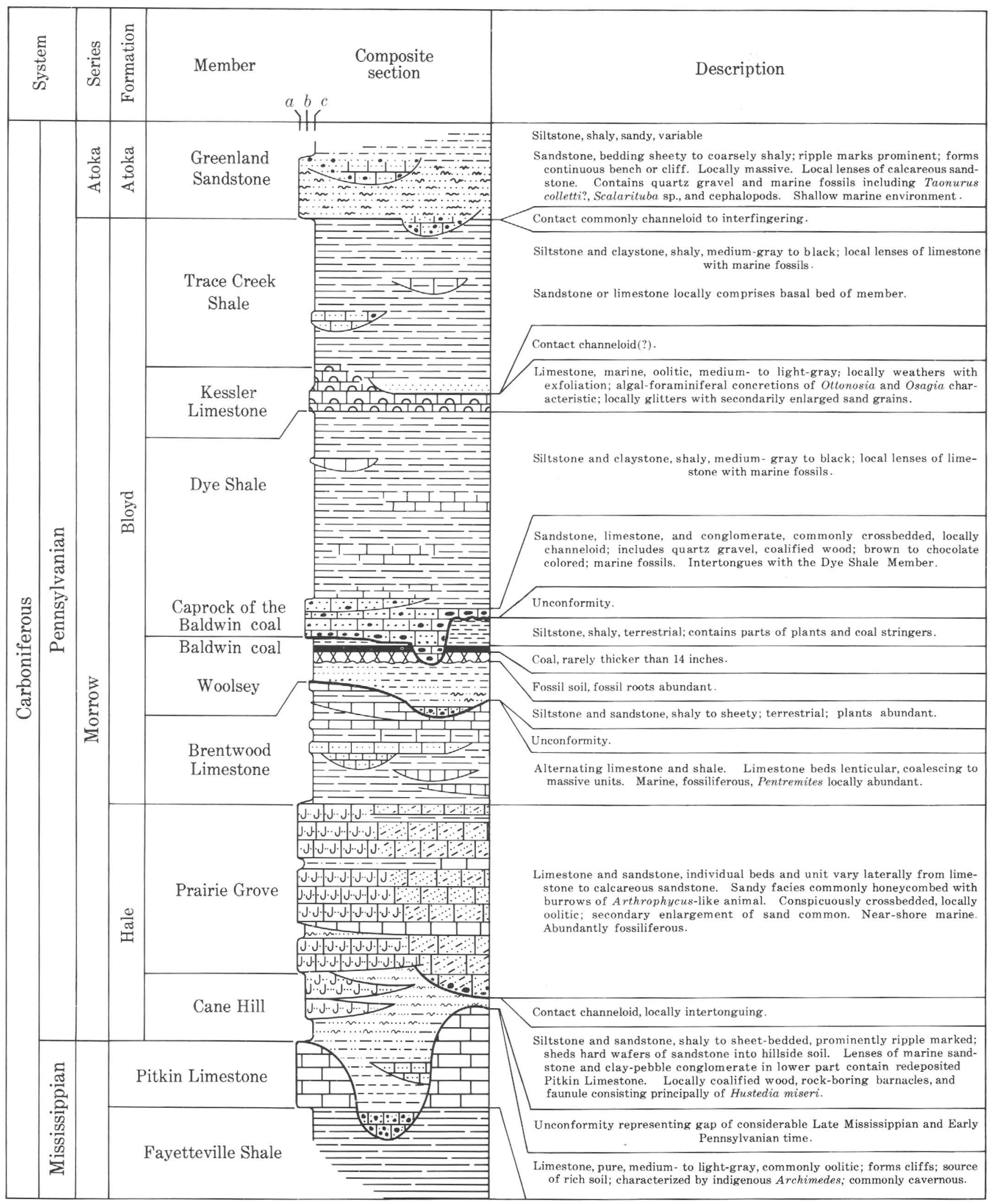

FIGURE 1.-Composite section of the type Morrow Series and adjacent rocks in Washington County, Ark. The topographic expression of the rock units is shown on the left side of the column: $a$, forms prominent cliffs or rock-controlled surfaces; $b$, forms local cliffs or benches; and $c$, forms subdued land surfaces. Vertical scale, 1 inch equals approximately 60 feet. (Modified from Henbest, 1962b.) 
are part of a depositional aggregate. Commonly, the ooliths and algal ooids are rather uniform in size, but the finer detritus is unsorted. No evidence has been found that indicates formation of ooliths and algal ooids within the sediment at the place of burial. All evidence so far recognized indicates that they were part of a mechanically deposited aggregate. The ooliths responded to compaction as firm, lithic bodies.

The preceding conclusion is supported by the fact that in all situations so far studied, the oolitic limestones of the Morrow display some combination of crossbedding, cut-and-fill bedding, sorting, and attrition of larger shell fragments. Normally, unsorted detritus filled interstitial space in the original sediment. Locally, however, the interstices were not filled. These interstices have since been filled with obviously secondary, sparry calcite cement.

The oolitic limestones of the Morrow are classed as mud-lean packstone of Dunham (1962). An environment of energy index IV of Plumley, Risley, Graves,

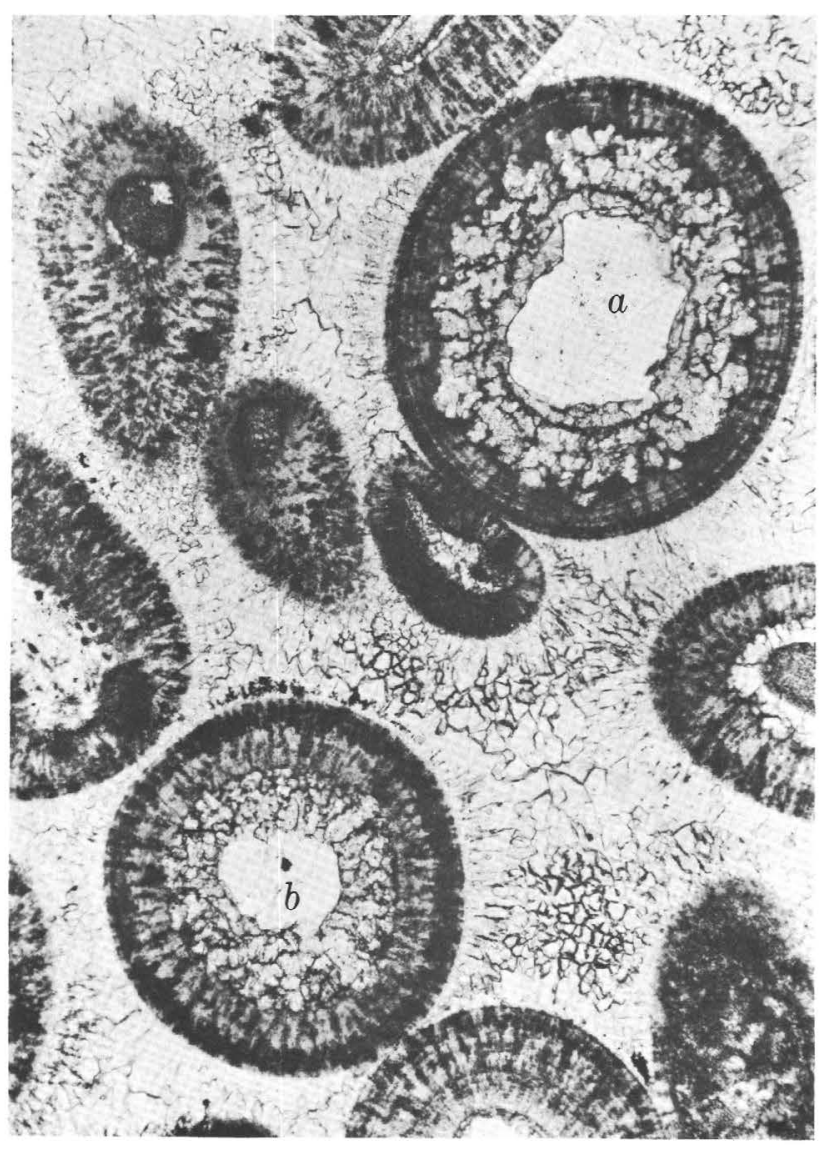

$\times 60$ and Kaley (1962, p. 88) is commonly represented. The sparry calcite in the matrix is a later emplacement connected with diagenesis. The common association in the Kessler Limestone Member of ooliths and large algal-foraminiferal colonies of Osagia Twenhofel, 1919, is another indication that the Morrow oolites were deposited in a high energy environment. As described in more detail elsewhere (Henbest, 1963, p. 17, 35), the species of Osagia evidently lived in the euphotic zone of the sea and required frequent rolling by waves or currents to produce concentric encrustations.

\section{DIAGENETIC STAGES}

The part of the diagenetic history with which this paper deals is divided into three stages. Figures 2-16 illustrate these stages of diagenetic history and the pertinent features of oolites. Stage 1 and stage 2 are each a combination of causally related, contemporaneous processes. Stage 1 consists of processes connected with compaction. Stage 2 consists of interactions, on a

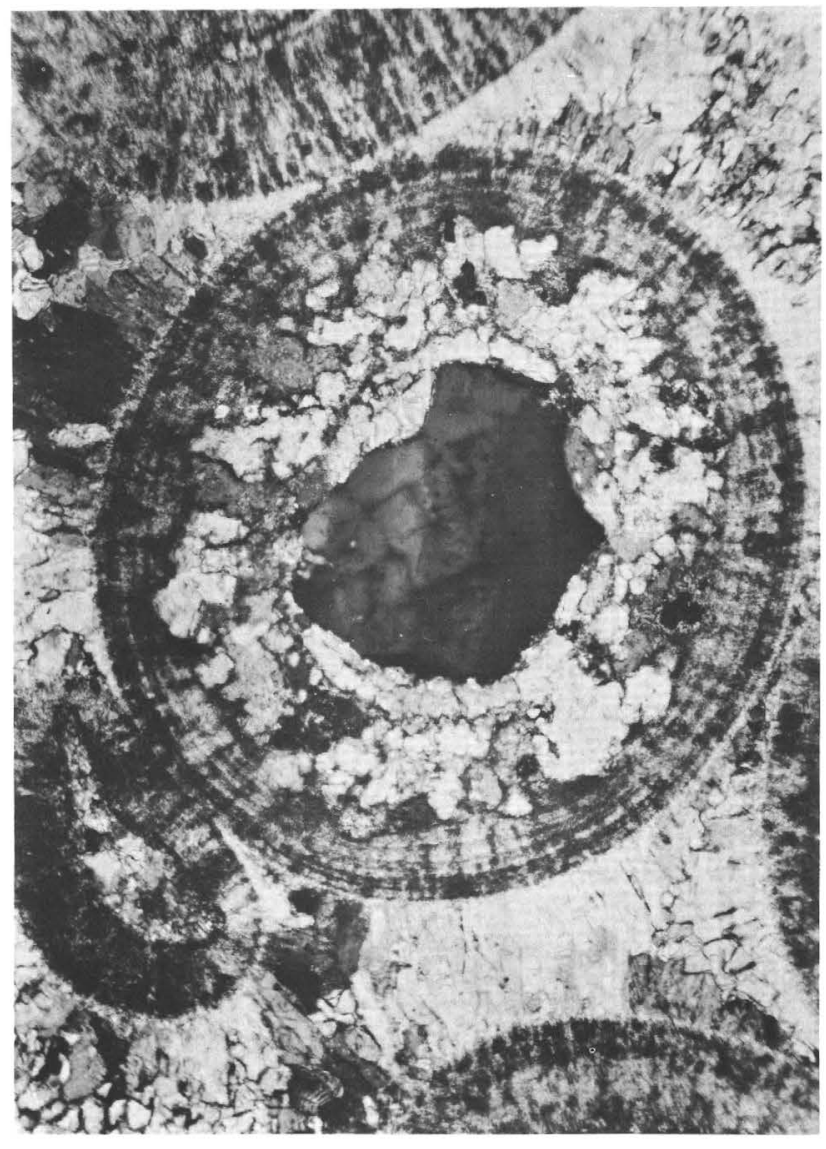

$\times 100$

FIGURE 2.-Ooliths with granular calcite in nuclei. Left photograph shows centered and eccentric sections. Right photograph shows part of same area in polarized light. Some granular calcite nuclei, as at $a$ and $b$, contain quartz grains. These granular calcite nuclei originally may have been pellets of lime mud, probably fecal pellets of a sediment-ingesting organism. In this particular part of the limestone, the interstitial space is filled with secondary, sparry calcite, which forms a distinct halo around the ooliths, but generally at this locality the matrix is a fine aggregate of bioclastic calcite, sand, clay, organic matter, and fossils. Prairie Grove Member of Hale Formation, USGS f862 (slide 1), USNM 110369. 


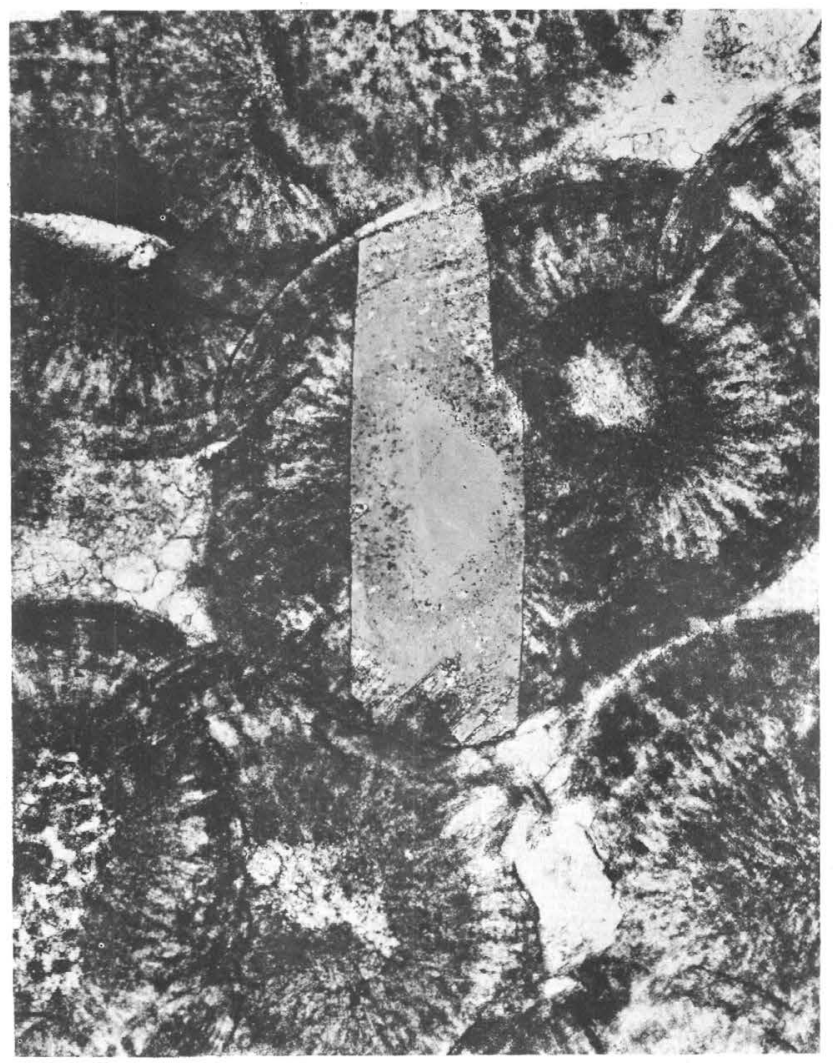

$\times 100$

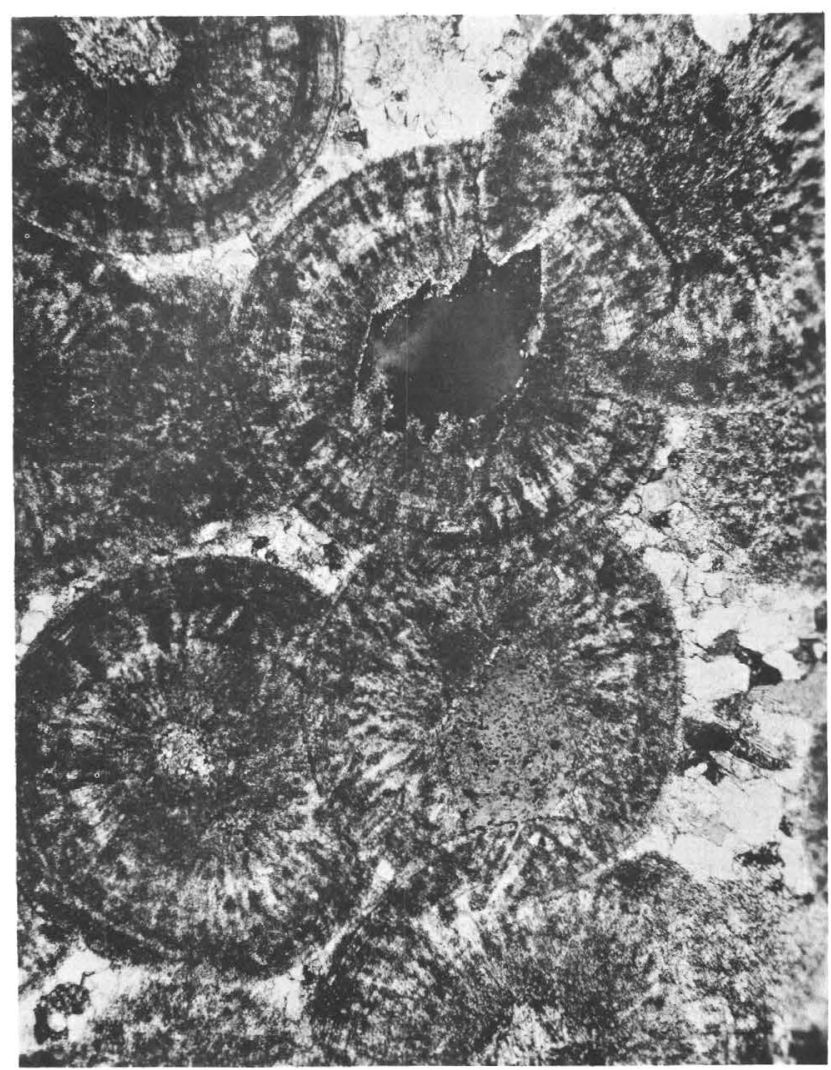

$\times 80$
4

Figure 3.-Microstylolitic interpenetration of ooliths of diagenetic stage 1 and quartz overgrowths of diagenetic stage 2. Polarized light. Both photographs are of areas in same thin section. In upper photograph, a rather typical overgrowth shows the ghost structure of the replaced part of the oolith and incorporates residual detritus from the antecedent microstylolite. The complicated or varied interpenetration and microstylolite patterns are shown in both photographs. The microstylolites commonly cut across the radial crystal structure of the ooliths. They are restricted to oolith contacts and do not extend into the matrix. The quartz overgrowths were emplaced after the microstylolite was formed. Bloyd Formation, USGS f886 (slide 4), USNM 110375.

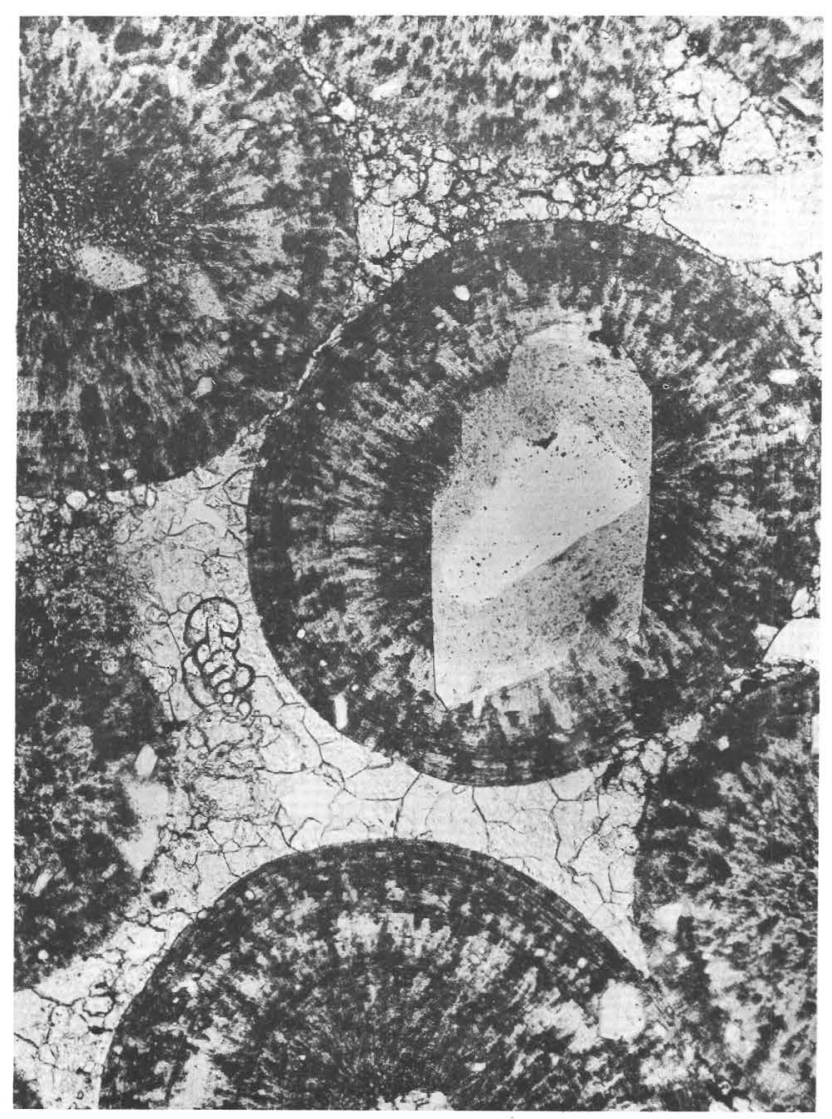

$\times 100$

$\triangle$

FIgURE 4.-Characteristic features of oolitic limestone in Bloyd Formation at Gaylor Ferry, Okla. Photograph shows secondarily enlarged quartz sand nucleus of an oolith, sparry calcite cement with random crystal orientation (compare with fig. 2), and a free, unusually well preserved shell of an apterrinellid foraminifer, Cornuspirinae-a sensitive indicator of good preservation. The relief on the sparry calcite is partly the result of acid etching in finishing the thin section and of stopping the substage condenser to about half the numerical aperture of the objective. Compare the termini of this overgrowth with those in figures 9, 15, and 16. Bloyd Formation, USGS f886 (slide 37), USNM 110378a. 


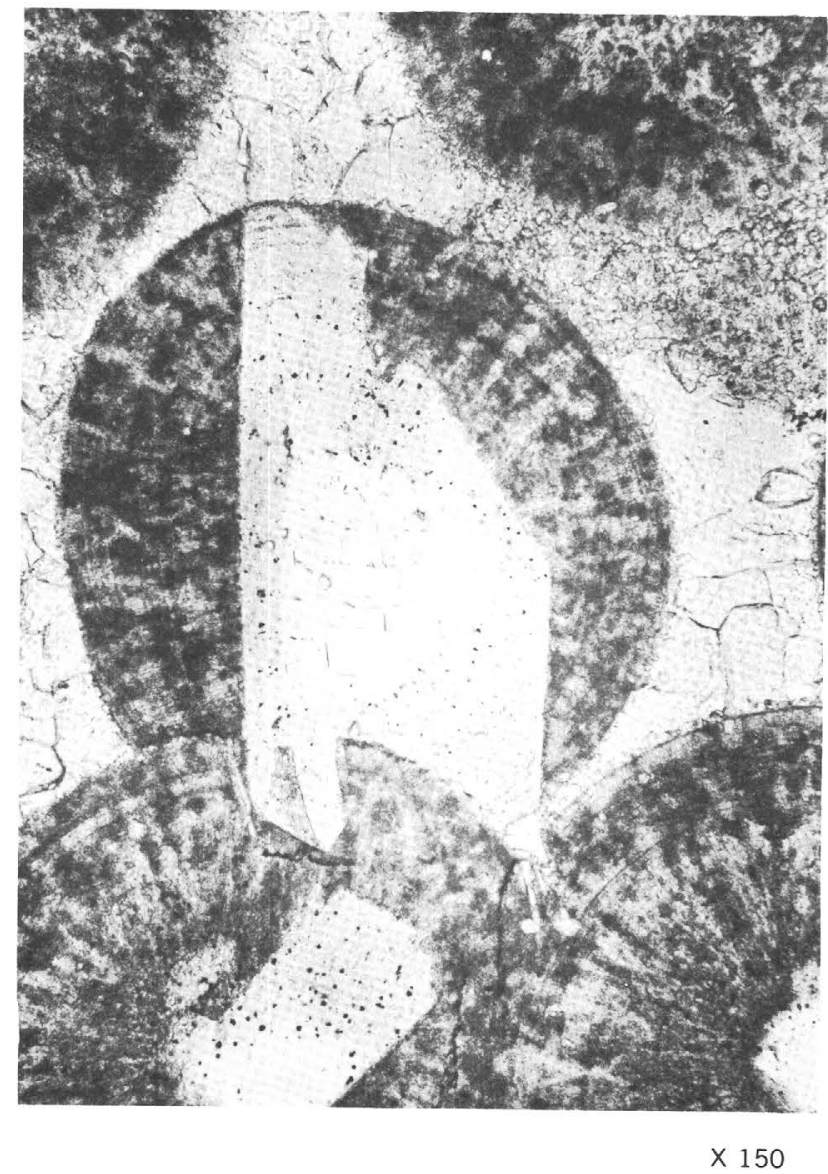

Figure 5.-Curved microstylolitic column incorporated by a subsequent quartz overgrowth. Variations in interpenetration directions in ooliths show that the ooliths rotated individually during compaction. This example also shows that the microstylolite of diagenetic stage 1 preceded the overgrowth of stage 2. Bloyd Formation, USGS f886 (slide 2), USNM 110374.

microscopic scale, of aragonite, calcite, and quartz that result in silica and calcite exchange. Before describing the diagenetic record, however, details of the lithologic setting are briefly described to eliminate irrelevant factors that might confuse interpretation of the record.

The part of the diagenetic history here described begins after the ooliths were formed and transported as firm, lithic grains to the site of burial. Thus we are concerned with ooliths as detrital particles and not directly with the tortured problem of their mode of formation.

Parts of the diagenetic record are more clearly recorded at one locality than at the others. To simplify description of the rather complicated history, the record at each locality is treated separately. The early stages of the diagenetic history are best represented at USGS locality f886, the old Gaylor Ferry on the Neosho River, Okla., which will be described first.

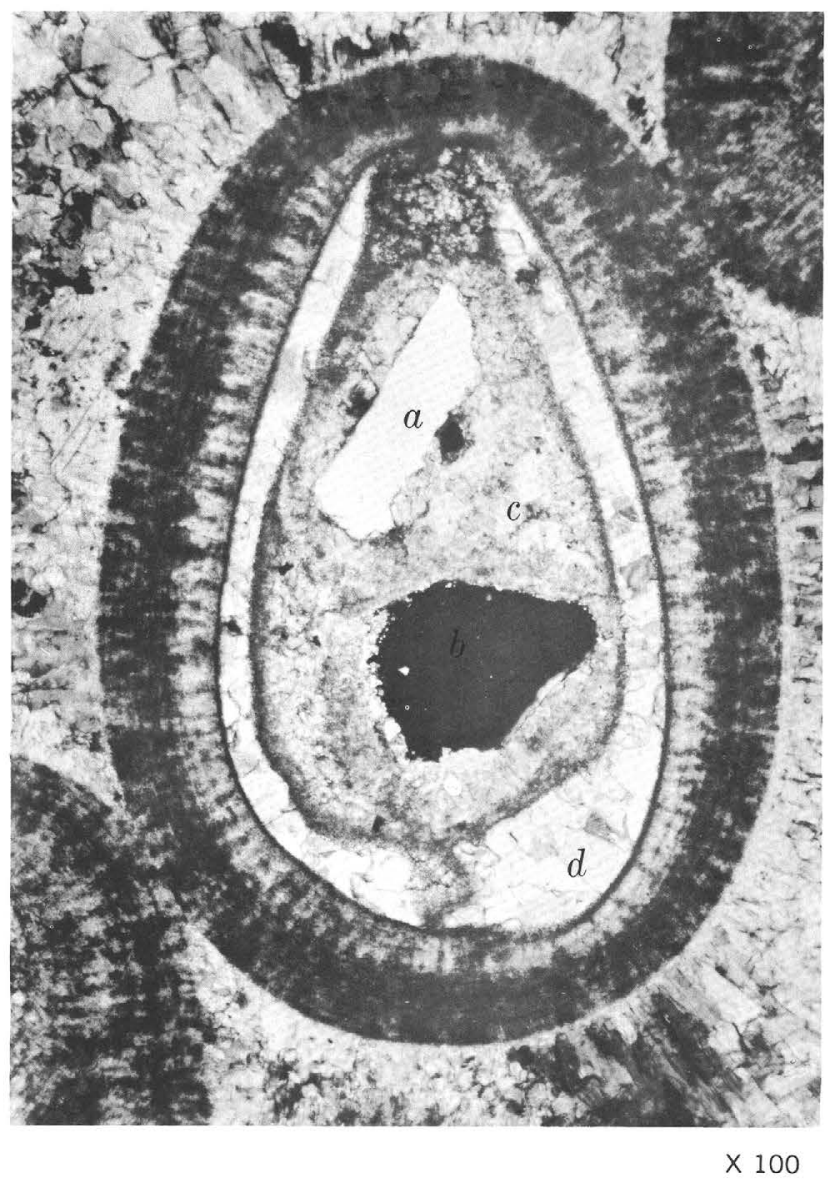

FIGURE 6.-Closed system of quartz-calcite exchange within an oolith. The nucleus consists of a minute immature pelecypod shell $d$ that was filled with calcitic silt $c$ and fine quartz sand grains $a$. Polarized light. Such pelecypod and other shells that are composed of a mosaic of sparry calcite and that contain no remains of the original shell lamellae are here regarded as originally composed of aragonite which was not stable and inverted at a very early diagenetic stage to crystalline calcite. The sand grains are slightly etched. From several other examples it may be concluded that at one or more places in this oolith above or below the plane of section, quartz grains touched the oolitic concretion and were secondarily enlarged. (See $a$ in fig. 7.) Prairie Grove Member of Hale Formation, USGS f862 (slide 1), USNM 110369.

\section{DIAGENETIC RECORD IN BLOYD FORMATION AT GAYLOR FERRY, OKLA.}

\section{LITHOLOGIC SETTING}

The ooliths at f886 are typical as to size, shape, and structure, and all have a single nucleus. The nuclei of a majority of the ooliths are grains of quartz sand. Invertebrate shell fragments, entire shells of small foraminifers, and siltstone fragments serve as nuclei for other ooliths. The quartz sand grain nuclei are clear crystalline quartz and have the usual variations that are found in most sandstones as to uniform or wavy ex- 


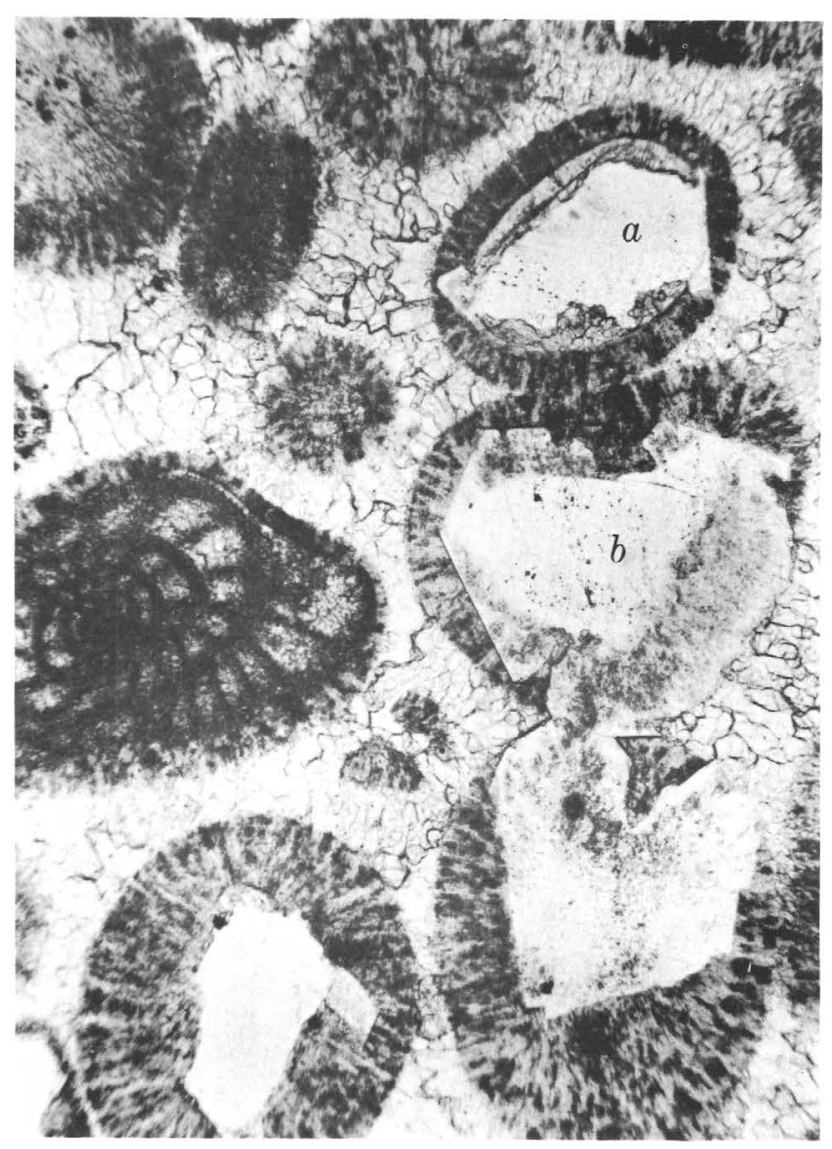

$\times 100$

Figure 7.-Ooliths with secondarily enlarged nuclei, illustrating a closed system of quartz-calcite exchange. The nucleus $a$. is a pellet composed of a quartz sand grain coated with granular calcite. It was probably a fecal pellet or a sand grain originally coated with lime mud. (See also figs. 2 and 6.) Where the quartz grain touches the calcite it is etched, but where it contacts the aragonitic concretion it is secondarily enlarged. Here, the silica transfer took place in a closed system less than a third of a millimeter across. The nucleus $b$ has a quartz overgrowth of the more common type. The seed grain is recognizable. Prairie Grove Member, USGS 1862 (slide 3), USNM 110370.

tinction, twinning, inclusions, and other evidences of different provenances.

The matrix consists in decreasing order of anhedral, sparry to cloudy calcite crystals, unrecognizable fragments of shells, nondescript grains of calcium carbonate, quartz sand, sparsely scattered foraminifer shells, abraded echinoderm plates, and fragments of bryozoans. The calcite crystals tend to form halos around the ooliths. Clay is scarce. If any carbonate "paste" existed it has been assimilated by the anhedral crystals of calcite. The quartz sand is unevenly distributed throughout the matrix.

Free shells of species of tubiform sedentary Cornu-

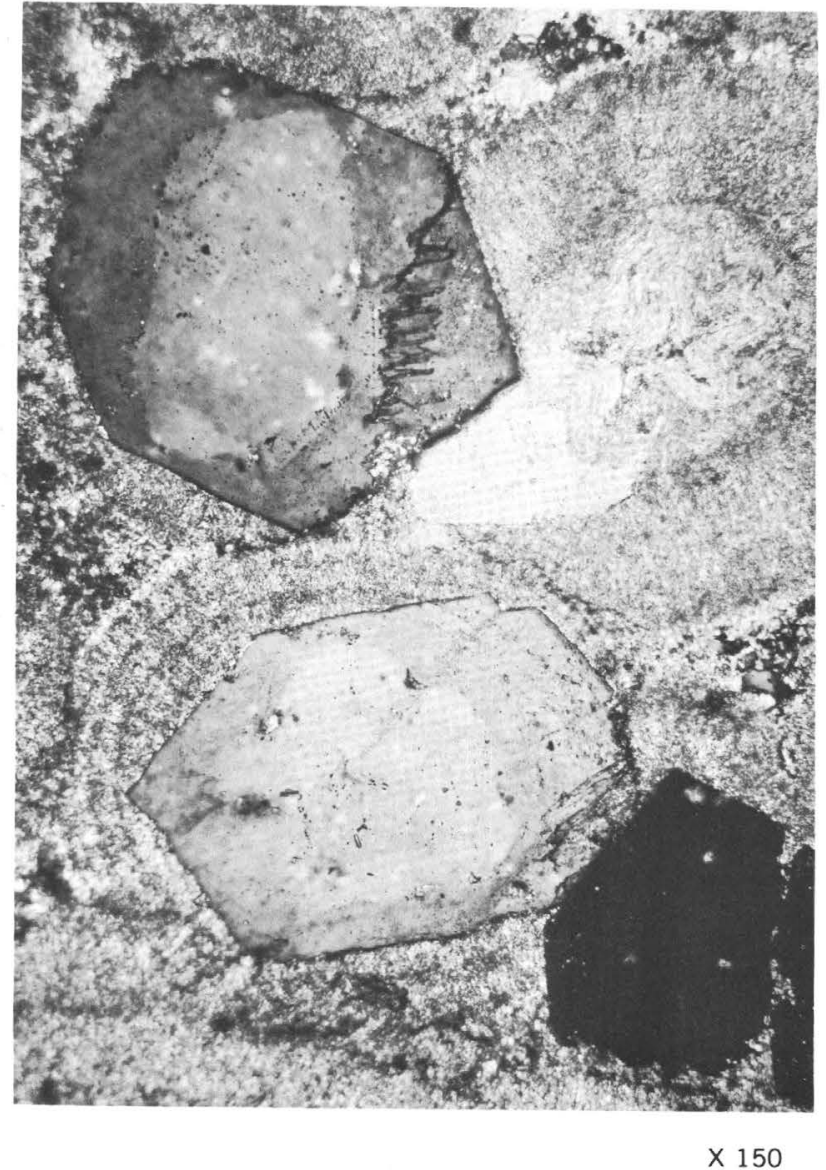

Figure. 8.-Microstylolite of diagenetic stage 1 incorporated by quartz overgrowth of stage 2. Polarized light. The microstylolites of diagenetic stage 1 were usually a barrier to quartz overgrowth. (See also figures 3 and 5.) A few overgrowths did penetrate microstylolitic barriers at one or more points, but rarely were such barriers completely breached and surrounded. Kessler Limestone Member of Bloyd Formation, USGS f7083 (slide 4), USNM 110379.

spirinae, Foraminifera, are sparsely scattered throughout this oolite. Their presence is of interest here because the state of preservation in cornuspirid shells is a sensitive indicator of the degree of diagenetic alteration in limestones. As discussed in more detail elsewhere (Henbest, 1963, p. 9-15), cornuspirid shells are secreted magnesian calcite. The shell material is amorphous within the limits of resolution by the visible spectrum, but contains minute polarization centers which have random orientation. The polarization centers are assumed to be submicroscropic crystals of calcite. Externally, the cornuspirid shell material has a whitish, porcelaneous luster, but in thin section it appears amorphous and brownish. Porcelaneous shell material is less stable than that of most associated calcite shells. In Paleozoic limestones the shells of cornuspirids are almost invariably altered to a dark finely granular end product with 


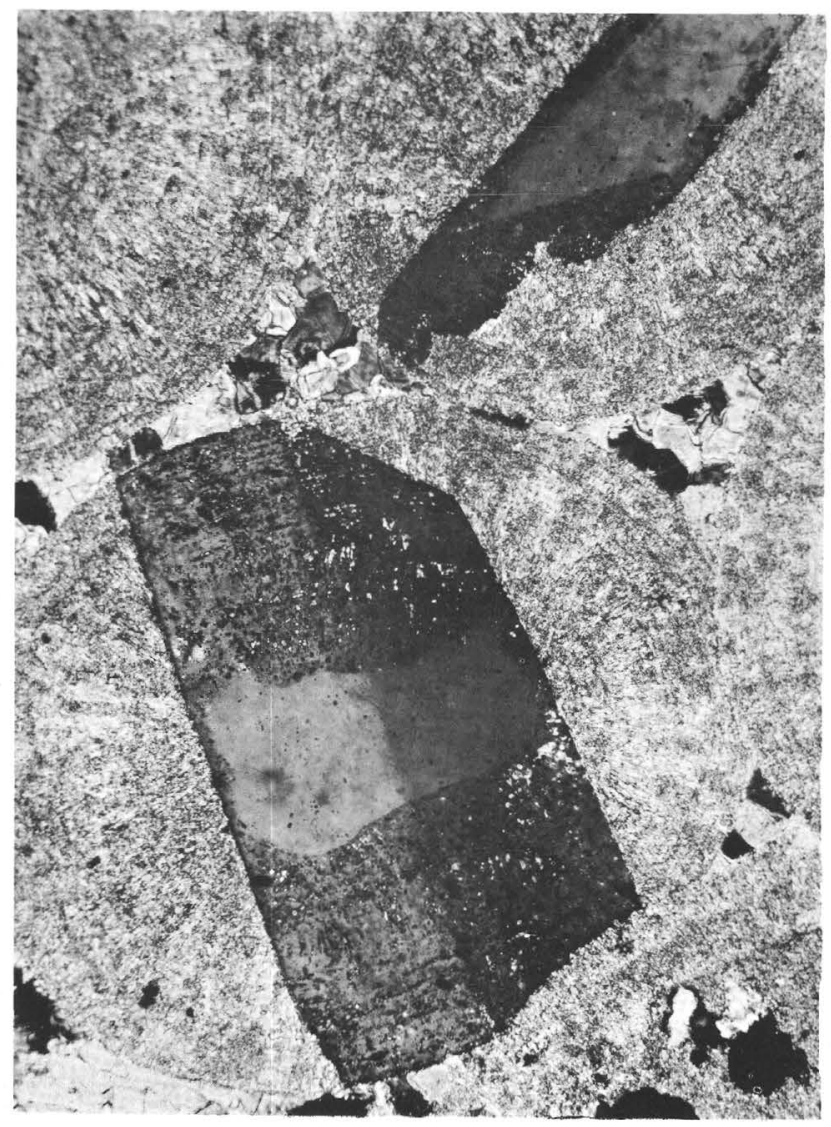

$\times 150$

Figure 9.-Quartz overgrowth with spheric terminations. Polarized light. This is a striking display of the seed grain and of the ghost of the replaced part of the oolith. The twinning of the seed grain is replicated in the overgrowth. Bloyd Formation, f886 (slide 31), USNM 110378b.

volume change and loss of fine surface sculpture. The cornuspirid shells in the matrix of the oolitic limestones here described have better-than-average preservation (fig. 4), but the shells of cornuspirids and the shells of other foraminifers that form nuclei of ooliths are poorly preserved. In oolitic limestone of other ages and at other places, carbonate shells that serve as nuclei of ooliths are nearly always poorly preserved. The oolitic limestone at $\mathrm{f} 886$ is no exception to the rule.

The porosity of this oolitic limestone is extremely low. Drusy cavities and euhedral calcite crystals are absent.

\section{DIAGENETIC STAGE 1, COMPACTION SYNDROMES}

Wherever the ooliths were so closely packed that they were supported by each other, they interpenetrated by microstylolitic action (figs. 3, 5, and 8). Interpenetration, presumably of a similar kind, in oolitic limestone in the Fredonia Member of the St. Genevieve Limestone of Mississippian age in southern Illinois was reported

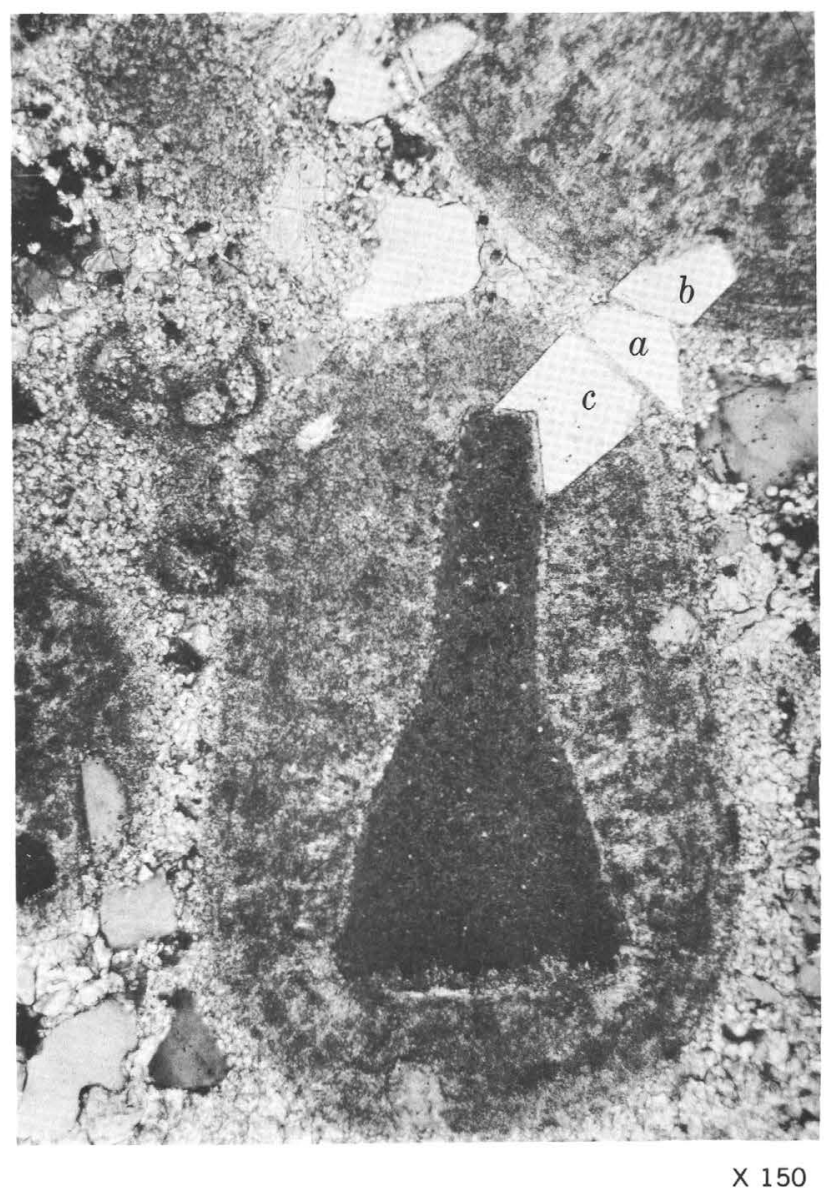

Figure 10.-Example of calcitic fossil, an echinoderm plate, acting as a barrier to growth of secondary quartz. Polarized light. In the plane of section, the seed grain $a$ was originally surrounded by matrix, but it evidently touched the two adjacent ooliths above or below the plane of section and crystals $b$ and $c$ penetrated the adjacent ooliths by replacement. The growth of the crystal at $c$ was arrested by the oolith nucleus, an echinoderm ossicle. Echinoderm ossicles are anhedral crystals of calcite and are more durable than other forms of biogenic calcite. The calcite of the ossicle was a barrier to quartz growth. Other quartz grains in the matrix show deep etching. Bloyd Formation, USGS f886 (slide 26), USNM 110377 .

by Graf and Lamar (1950, p. 2332) and Carozzi (1960, p. 248-250).

The microstylolites are restricted to contacts between ooliths. No microstylolites extend from between ooliths into the matrix, and none exists at the interface of ooliths and matrix. The boundary between matrix and ooliths is generally well preserved and distinct. Wherever large competent particles in the matrix, such as fragments of bryozoans and echinodern ossicles or sand grains, were pressed by compaction into the ooliths, the penetration boundary is but slightly, or not at all, stylolitic. A few ooliths were split or ruptured by contact pressure. 


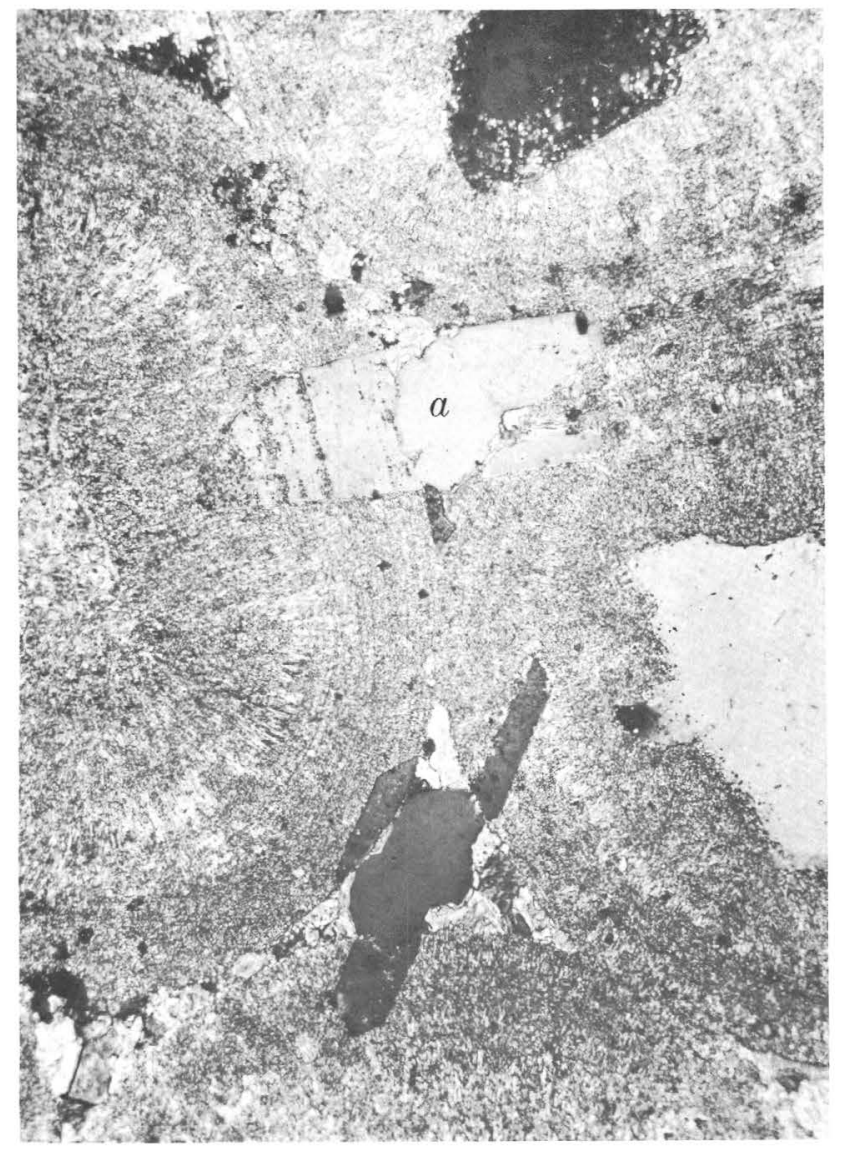

$\times 150$
Superficially, the microstylolites appear to have a somewhat random direction and distribution, but the randomness has not been tested statistically in oriented samples. At any one contact, most of the invasion is commonly, but not always, done by one of the interpenetrating grains. At other contacts, however, the "aggressor" grain may itself be invaded (fig. 3). The microstylolites lack any sort of alinement or distribution that suggests a former continuity through a lithified matrix. This condition, together with the restriction of microstylolites to contacts between ooliths, indicates that interpenetration occurred before final cementation and lithification.

The aragonitic zone in the ooliths is strikingly free from inclusions of detritus, adherent particles, and externally imposed deformations in growth pattern. The nuclei were single cleanly washed grains. The ooliths were individally and fully formed and were rigid, competent bodies before transportation to the site of burial.

Figure 11.-Example of combined etching and secondary enlargement of quartz sand grains. Polarized light. Two quartz grains in the matrix touched ooliths and were secondarily enlarged into the ooliths. As in figure 10, the seed grains are etched wherever exposed to matrix. The upper right apophysis of seed grain $a$ appears to have grown in the matrix, but a. careful examination showed that it grew into a fragment of an oolith. Bloyd Formation, USGS f886 (slide 10), USNM 110376 .
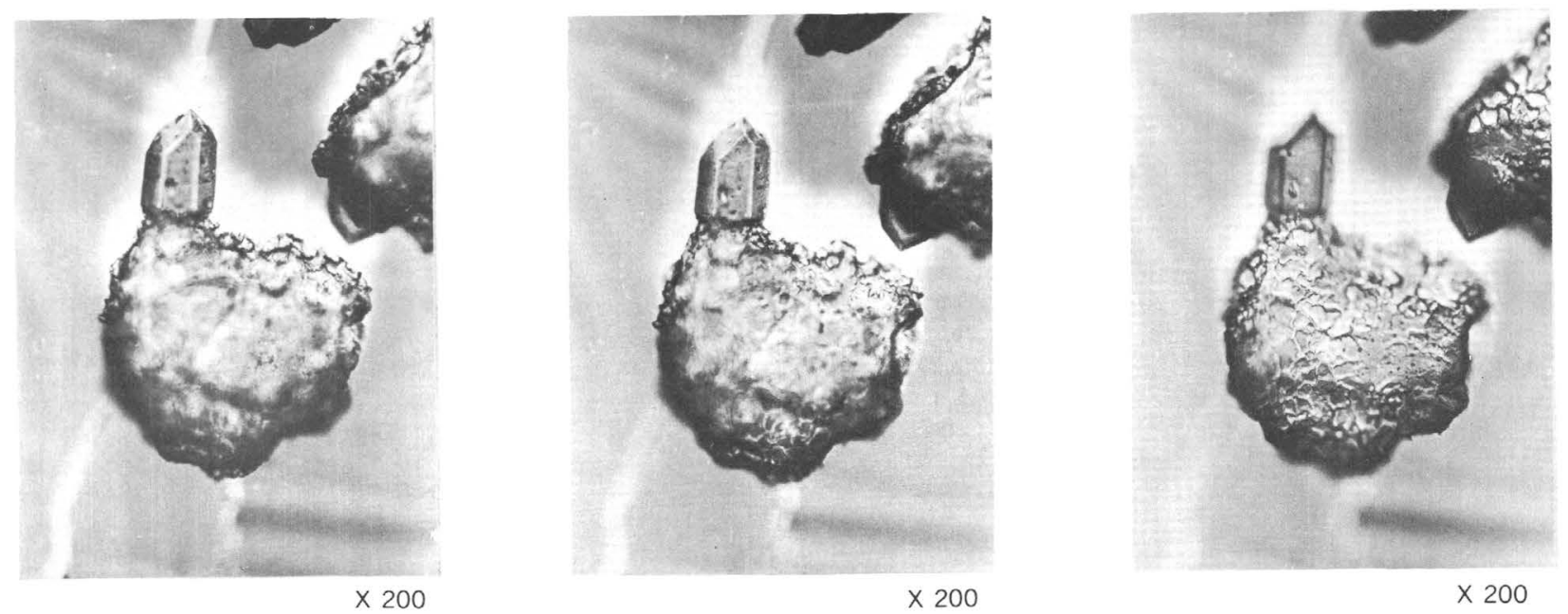

FIGURE 12.-Serial views of quartz seed grains showing solution-etch figures and secondary crystal growths. Isolated from oolite by hydrochloric acid and cleaned by Clorox at $100^{\circ} \mathrm{C}$. Photographed by transmitted light, Wratten $\mathrm{B}$ (green) filter. Compare with figures 10 and 11, which show thin sections of similar specimens. The focal planes of left and center photographs are $0.005 \mathrm{~mm}$ apart, and those of center and right photographs are $0.010 \mathrm{~mm}$ apart. As also shown in figure 14, the form of the etch figures is unrelated to the crystal structure of the quartz seed grain. The etched surface of the seed grain marks the areas of contact with calcite grains in the matrix. The base of the secondary quartz crystal marks the point of contact with an oolith. A minimum measure of the amount of loss by solution etching is indicated by the depth of the etch pits and is suggested, with some ambiguity, by the shape of the necking at the base of the secondary crystal. The specimen was vapor coated with silver, darkened by hydrogen sulfide gas. Bloyd Formation, USGS f886 (slide C1), USNM 110372 . 


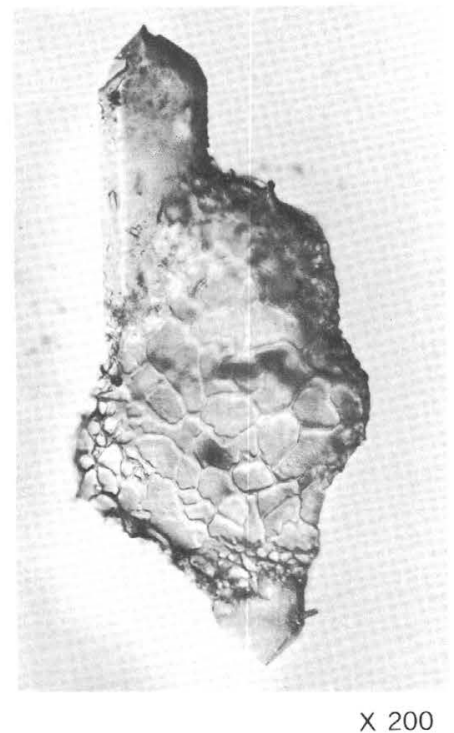

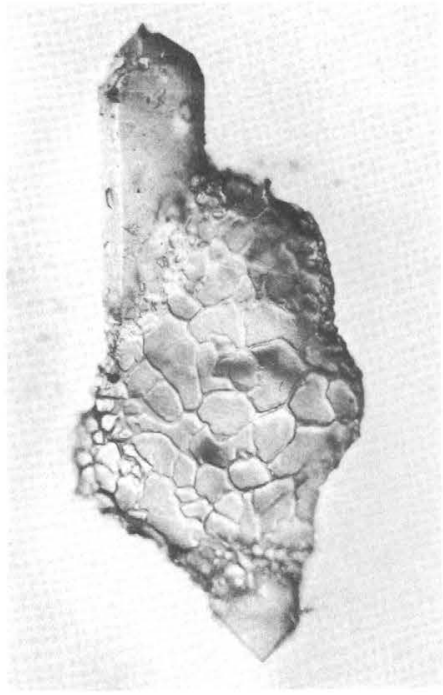

$\times 200$

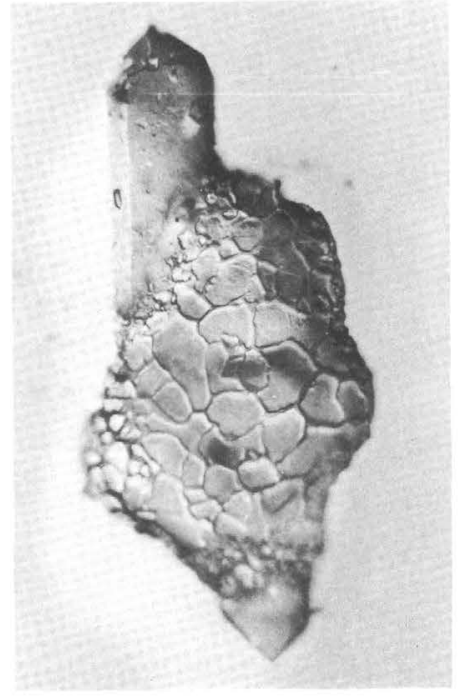

$X 200$

FIGURE 13.-Data and commentary same as for figure 12 except that the source was USGS f886 (slide C4), the focal planes are separated by $0.003 \mathrm{~mm}$, and the vapor coating was made with chromium, which was subsequently darkened by hydrogen sulfide. USNM 110373.

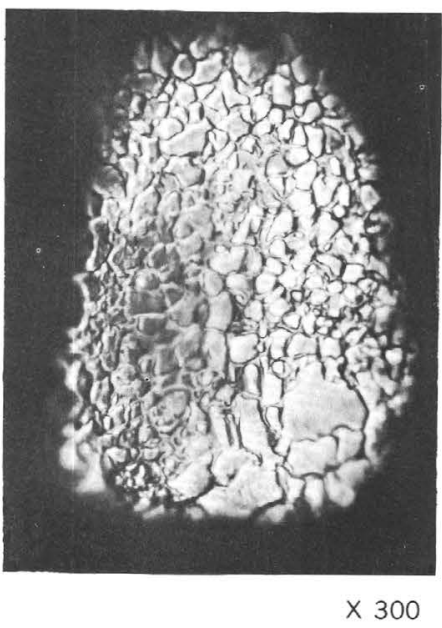

Figure 14.-Etch pattern in quartz grain from matrix. Polarized, transmitted light. Vapor coated with chromium and exposed to hydrogen sulfide gas. Here, as in figures 12 and 13 , the etch figures reflect the size and shape of the adjacent anhedral crystals of calcite and seem to be unrelated to the crystal structure of the quartz grain. Bloyd Formation, f886 (slide C4), USNM 110373.
The microstylolitic solution in stage 1 must have displaced considerable aragonite in the areas of closely packed ooliths. It is assumed that the aragonite was redeposited as calcite cement. In the few samples at hand, however, most ooliths are matrix supported. High-density packing occurs locally. Though the total amount of displaced carbonate was not large, enough for considerable cementation was probably released if the present samples are representative. This raises a problem because the matrix behaved as an unlithified sediment during the microstylolitic action. It is necessary to conclude either that the free carbonate was carried out of the compacting sediment or that intergranular adjustment took place by repeated solution and redeposition of calcite at pressure points during cementation. The second conclusion is supported by the evidence from the Morrow and by Robertson's (1955) experiments on the strength of limestones.

Support for the second conclusion is also found in Ubehebe Canyon in the Death Valley area, California, where extensive plastic flow has deformed Permian limestones without fracturing, brecciation, coarse recrystalization, or marks of loss of cohesion. Furthermore, the plastic deformation shows a minimal amount of deformation by gross solution transfer, though contact solution transfer must have occurred, perhaps extensively, on a submicroscopic scale. These observations conflict sharply with the rather common tacit assumption that wherever a loss of cohesion in a sedimentary rock body is not in evidence, cementation occurred during a state of rest. 


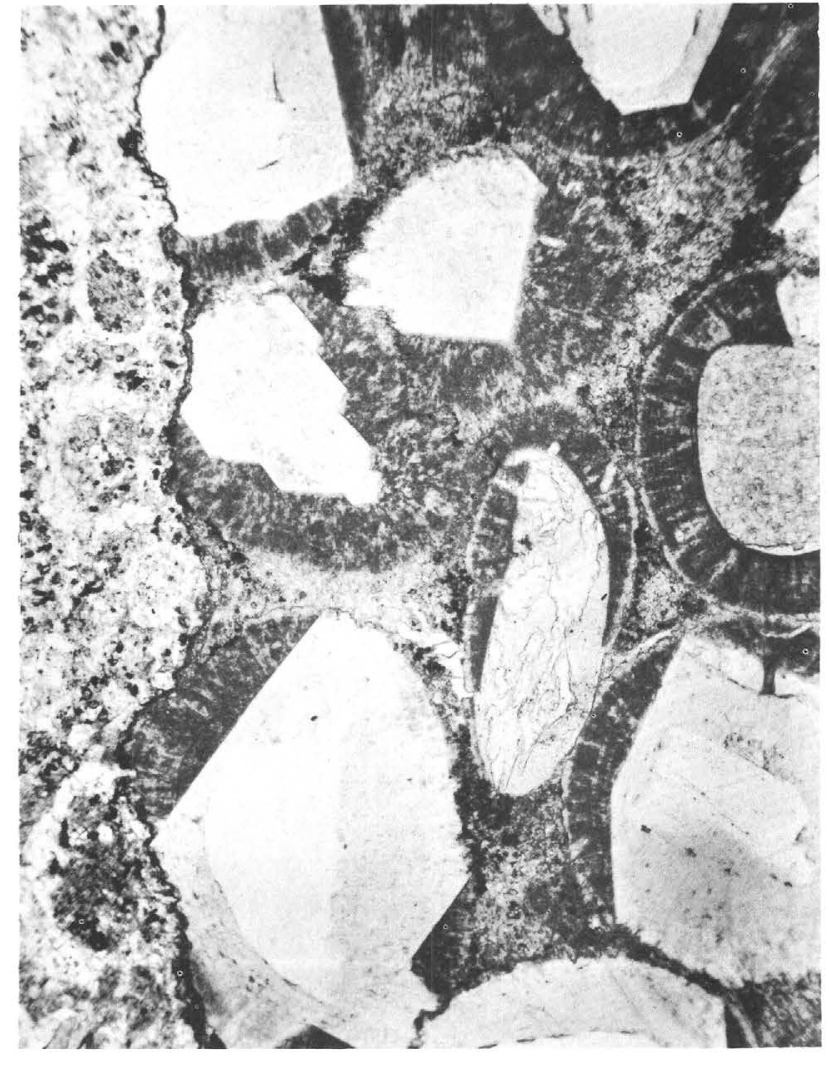

$\times 80$

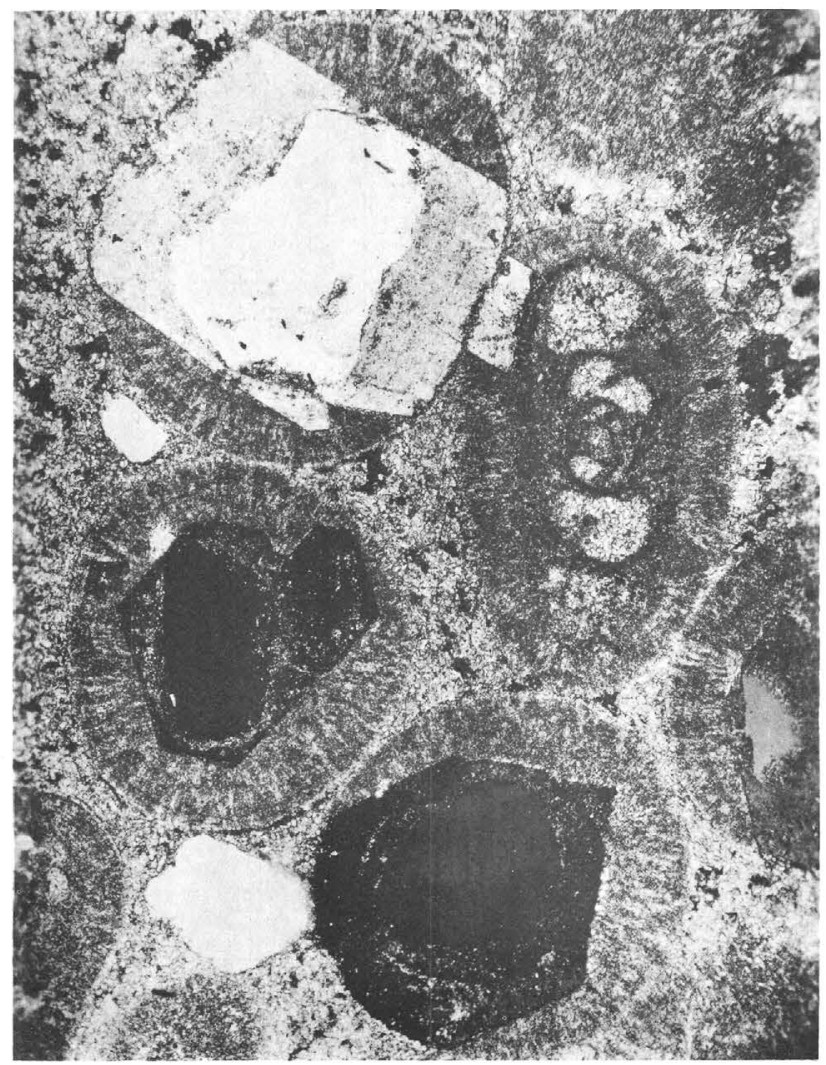

$\times 80$

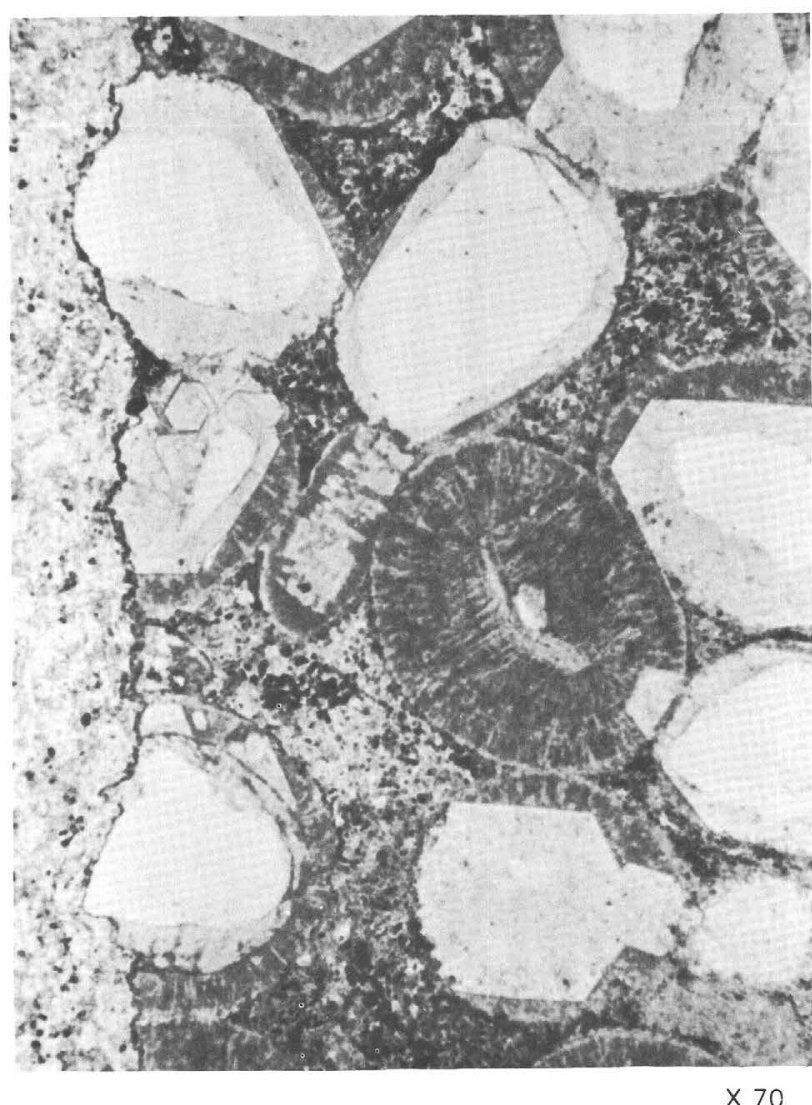

Figure 15.-Contact between an algal-foraminiferal colony, ottonosia sp. (at left in both photographs), and its nucleus, an exotic cobble of oolitic limestone. Along the contact between Ottonosia and the exotic cobble, the seed grain and overgrowths have different relief. In left photograph, the overgrowths seem to have similar relief to that of the adjacent aragonitic zones of the ooliths. In right photograph, the overgrowths have higher relief than the adjacent carbonate; thus the evidence indicating relative age is mixed or ambiguous. As in figure 16, most of the carbonate in the fossil of Ottonosia and that in the exotic cobblestone which remained after diagenetic stage 2 were replaced by microgranular silica of diagenetic stage 3. Basal conglomerate of the Kessler Limestone Member of the Bloyd Formation. USGS f871B; left photograph shows an area in thin section 37 , and right figure an area in thin section SS 1 ; both from same specimen. USNM $110371 \mathrm{a}$ and $\mathrm{b}$, respectively.

4

Figure 16.-Exotic cobble of oolitic limestone from basal conglomerate of Kessler Limestone Member of the Bloyd Formation showing diagenetic stages 2 and 3. Polarized light. Most nuclei were single quartz sand grains, but particles of invertebrate shells or echinoderm ossicles and entire foraminifer shells also served as nuclei. The overgrowth at upper left had spheric terminations except where it penetrated an adjacent oolith and impinged against and was stopped by the shell of Endothyra sp., whose shell was probably magnesian calcite. Same thin section as in figure 15, left photograph. 


\section{DIAGENETIC STAGE 2, QUARTZ AND CARBONATE EXCHANGE}

A striking feature of the Morrow oolites at locality f886 is their nuclei of euhedral crystals of quartz. As previously explained for the occurrence at locality 1771 in Arkansas (Henbest, 1945), each quartz crystal consists of two parts: an inner seed grain of quartz sand and an outer euhedral overgrowth that contains a ghost or relic of the part of the oolith that the quartz overgrowth replaced. Not only are the quartz sand nuclei enlarged, but wherever quartz grains in the matrix merely touch or have been pressed by compaction into an oolith, they are enlarged at the point of contact with the oolith (figs. 10 and 11). These same quartz grains are etched wherever they touch the matrix.

All quartz overgrowths are restricted to the interior of ooliths (figs. $3-5,7-11,15$ and 16). No overgrowths extend from inside an oolith into the matrix. No overgrowths originate, or are present, in the matrix.

All quartz grains "floating" in, or exposed to, the matrix were solution etched if they were near ooliths that had quartz grain nuclei. The degree of etching seems to have depended on the nearness of the etched grains to ooliths with quartz grain nuclei.

The microstylolites were a barrier to growth of secondary enlargements of the quartz nuclei. At a few places, one or more minute extensions of a secondary crystal penetrated a microstylolite and grew into the adjacent oolith, and, more rarely, an overgrowth incorporated a microstylolite (fig. 8). Wherever the growth of a secondary quartz crystal was arrested by a microstylolite, the termination of the overgrowth conformed in minute detail to the stylolitic surface and generally incorporated residues or alteration products that remained from the microstylolitic action (figs. 3, 5, and $8)$. The microstylolitic surfaces between the ooliths display the usual features of stylolites between carbonate masses in other limestones and in marbles, notably interpenetration columns, impermeable film, and a thin zone of insoluble residues and alteration products. The stylolitic terminations on the quartz overgrowths are so unlike the surfaces made by pressure solution contacts between quartz grains that confusion is impossible. All evidence so far seen agrees in indicating that the microstylolites antedated the quartz overgrowths.

As would be expected, insoluble residues from the oolitic limestone at locality f886, and from the other Morrow oolites with secondarily enlarged nuclei, contain an odd and varied assortment of quartz grains. These include well-faceted quartz prisms terminated by pyramids, spherical surfaces, or microstylolitic surfaces, or by a combination such as a euhedral pyramid on one end and a hemisphere on the other; etched quartz grains from the matrix (fig. 14); and etched quartz grains with one or more euhedral crystal apophyses (figs. 12 and 13). The spheric termini represent the outer surface of the oolith beyond which a crystal could not grow (figs. 9, 15 and 16).

The overgrowths usually contain microscopic residues of the aragonitic structures that were replaced. These residues together with minute dark inclusions of undetermined composition and source, form a ghost of the replaced structure. The pattern of the ghosts can be traced in detail into the aragonitic structures that remain in the oolith and leaves no doubt that the overgrowths are replacements.

The overgrowths generally conform closely to the optic orientation of the seed. Twinning in the seed is extended into the overgrowth in various degrees of conformity. In a thin section, wherever differences show between the extinction positions of the seed and of the overgrowth, it is to be suspected that the overgrowth may replicate a twin in a part of the seed that was above or below the plane of section. Wavy extinction, however, may be partly, or not at all, replicated.

The quartz overgrowths have a smoky or brown color. The seed grains are commonly clear crystalline quartz. As noted above, the overgrowths contain minute inclusions whose arrangement replicates the oolith structure which was displaced. The larger of these inclusions are dark and 1-3 microns across and have an irregular shape. They tend to be zonally distributed around the seed in conformity with the ghost of the oolith concretion.

A sample of the oolite was digested in a 5 percent solution of hydrochloric acid. The residue was boiled for 1 hour or more in normal hydrochloric acid and then boiled for 2 hours in full-strength Clorox ( 5.25 percent sodium hypochlorite). It was then washed, dried, and, finally, heated in a crucible for about 2 hours at orange temperature. Most of the seed grains were not changed, but the overgrowths were darkened; some turned black. This test indicates that the inclusions are organic, but some metal salts would react similarly if present.

Thin sections and insoluble residue from f 886 were submitted to Edwin Roedder of the U.S. Geological Survey for determination of the inclusions in the quartz overgrowths. His report (written commun., March 23, 1967) follows:

I have examined the overgrowths in three samples for oil inclusions, and must admit defeat. The index of refraction of the overgrowth differs very slightly from that of the core, and it has a definite overall brownish color. This is not just due to the presence of numerous colorless, colored, and opaque inclusions in the overgrowth, as the quartz between these is also colored. The cause of this coloration is not resolvable at $\times 1500$. 
It may represent impurities (organic?) concentrated along the innumerable discontinuities in the overgrowth structure that must be present owing to the inclusion of so many foreign particles. Most of the larger inclusions in the overgrowths are incompletely replaced carbonate from the ooliths, as they occur in curving trains representing the original oolite structure. In addition, however, there are numerous inclusions of reddish material and of opaque matter. Although one would normally guess that the former are iron oxides, both varieties could be organic matter. A few of the reddish inclusions show birefringence, and, hence, these are probably hematite. A few milligrams of the grains were ignited in a closed tube to see if a petroliferous odor could be detected, but no odor was found; a larger sample would give a much more sensitive test.

The only good liquid inclusions visible in these crystals are artifacts from the environment of formation of the quartz grains that form the cores. A number of large inclusions were found with gas: liquid ratios indicating high formation temperatures. Several grossly different environments are evident, as the gas: liquid ratios differ widely, and the composition of the liquid differs as well, as seen from the response of the bubbles in them to thermal gradients.

Two nuclei were found that were composed of very fine grained colorless completely quartz cemented quartzite. The grains in the quartzite had random crystallographic orientation. These nuclei had no quartz overgrowths, though adjacent ooliths contained normal overgrowths.

As judged by superficial examination, and as might be expected, the quartz grains in the matrix and the secondarily enlarged seed grains in the ooliths have random orientation.

It is significant that wherever an overgrowth from a tangential quartz grain penetrated to the center of an oolith whose nucleus was a calcitic foraminifer shell or a fragment of a calcitic invertebrate shell, growth was stopped by the calcitic nucleus (figs. 10 and 16). Furthermore, no overgrowths have been found in calcite shells in the matrix or in algal-foraminiferal fossils such as Osagia and Ottonosia Twenhofel, 1919, whose shells were probably magnesian calcite and may have contained some, if slight, residues of organic matter, but no aragonite.

Siever's (1959, p. 69, fig. 3) proposal, regarding a different situation, that well faceted quartz grains may be formed by "solution of detrital grains along definite crystal zones," does not apply here. There can be no question that these quartz crystals are secondary enlargements. The presence of relics or ghosts of the oolithic structure in the overgrowths is unmistakable evidence for secondary enlargement. The absence of crystallographic solution-etch figures from the etched quartz grains in the matrix is concomitant evidence.

The only other quartz objects in the limestone that received secondary enlargements were sand grains in agglutinate shells of the tubiform foraminifer Minammodytes Henbest, 1963. Minammodytes built its shell by cementing bottom detritus, mostly quartz grains of clay and silt size, into a shell material analogous to concrete. The nature of the original cement of Minammodytes is unknown, except that it was probably some form of calcium carbonate.

A considerable volume of carbonate was displaced from the ooliths by secondary enlargement of the quartz grain nuclei. Now, the principal components of the matrix are anhedral calcite crystals and remains of carbonate grains, some of which are recognizable as remains of the original bioclastic sediment. The anhedral calcite crystals are partly sparry and are clearly of secondary origin, but some incorporate or extend the crystal structure of recrystallized detrital grains. At this stage of study, the various generations of calcite cement have not been identified with the diagenetic events, except that the calcite that fills the solution pits in quartz grains was derived from the ooliths during the carbonate-silica exchange of diagenetic stage 2. These anhedral calcite crystals are minute and have random orientation. They do not form distinct, recognizable patterns of crystal orientation around the etched quartz grains.

\section{DIAGENETIC STAGE 2 IN PRAIRIE GROVE MEMBER OF HALE FORMATION, ARKANSAS}

The diagnetic history of the Prairie Grove Member of the Hale Formation near Fayetteville, Ark. (USGS f771, f862, and f4831) resembles that at Gaylor Ferry (USGS f886), except that diagenetic stage 1 is but rarely displayed. The quartz overgrowths at these localities in Arkansas are less extensive and reach the outer surface of the ooliths less frequently than those at Gaylor Ferry; so, a greater number of overgrowths are doubly terminated euhedral crystals.

The diagenetic record at $\mathrm{f} 862$ contains some interesting variants from those at $f 771$ and $f 886$. The matrix at some places in the oolite at 8862 consists entirely of anhedral crystals of sparry calcite. These form distinct halos around the ooliths. At such places, the interstices were probably voids originally. A few ooliths at $\mathbf{f} 862$ have a minute carbonate pellet as a nucleus. These pellets are dark and consist mainly of minute grains of calcite and some quartz grains of silt or clay size. It is thought that these small aggregates are of fecal origin. The aragonite covering of the nuclear pellet has the characteristic radial and concentric layers of normal ooliths (figs. 2, 6, and 7). Wherever a quartz sand grain inside the pellet touched the outer aragonitic zone of the oolith, the sand grain is secondarily enlarged at the point of contact into the aragonite; but wherever the other sides of the same quartz grain touched the granular calcite of the nucleus, the grain was etched and not enlarged. The microgranular calcite inside the pellet 
plays the same role as the calcite in the matrix. Here the silica-carbonate exchange operated in a closed system within an oolith, a realm in some ooliths as small as 0.05 mm across.

Secondary enlargement of quartz sand nuclei has been found at a number of other localities in the Prairie Grove Member. It is probably a rather common feature in Washington County, but a systematic search for its distribution has not been made. The occurrences at $\mathrm{f} 771$ are the most spectacular display in the Prairie Grove. In the other samples from the Prairie Grove the ooliths are more sparse, the aggregate that composes the matrix is more varied, and the causal relationships of diagenetic stages 1 and 2 are not as clearly indicated as at locality f886, Gaylor Ferry.

In my 1945 paper (p. 22; discussed also by Carozzi, 1960$, p. $257-258)$, it was noted that emplacement of the overgrowths took place without bursting the ooliths. This was offered as evidence that the ooliths were supported during emplacement by interstitial cement, an argument that I now question.

\section{DIAGENETIC STAGES 2 AND 3 IN KESSLER LIMESTONE MEMBER OF BLOYD FORMATION}

Ooliths that have secondarily enlarged nuclei are found at several localities in the Kessler Limestone Member of the Bloyd Formation in Washington County, Ark. At some of these localities, algal-foraminiferal colonies of Osagia and of Ottonosia Twenhofel, 1919 , are selectively replaced by spongy microcrystalline silica. Wherever replacements by microcrystalline silica and quartz overgrowths of diagenetic stage 2 occur together, the overgrowths are enclosed without alteration. No causal relationship between the overgrowths and the cryptocrystalline silica is recognized. The microcrystalline silica was introduced at a later time, here called diagenetic stage 3. Chert is unknown in the Kessler of this part of Arkansas and adjacent Oklahoma.

A silicified colony of Ottonosia from the Kessler at its type section (USGS f871B) is described first because it is both a good example of diagenetic stage 3 and a possible key to the date of diagenetic stage 2 . It is described in detail because the date of cementation and of the processes commonly associated with diagenetic stage 2 are critical and still unsettled issues in reconstructing the evolutionary history of marine limestones and sandstones after deposition and burial.

This particular silicified colony of Ottonosia is one of many similar colonies in a local conglomerate in the base of the Kessler Limestone. The aggregate of this conglomerate is composed largely of algal-foraminiferal colonies from the size of small concentric Osagia to massive asymmetrical Ottonosia a decimeter or more across. As the colonies grew too large for turning by waves, they coalesced into more massive colonies. There can be no question that these colonies are indigenous and that they are of eary Kessler age. The colonies were algal-foraminiferal consortiums or alternating growth in the euphotic zone of the sea (Henbest, 1963, p. 17, 35). The conglomerate includes a few exotic cobbles as well as locally derived detritus. The cobbles served as nuclei of algal-foraminiferal colonies. One nucleus is a wellrounded cobble of oolitic limestone that is unlike any oolitic bed so far seen in the immediate area of the Kessler. The ooliths are closely packed, and their quartz grain nuclei are more extensively enlarged than those of the scattered ooliths in the surrounding limestone.

The smooth surface of this cobble, the virtual absence of differential abrasion between the ooliths and interstices, and, particularly, the absence of staining and infiltrated detritus from the interstices at the outer surface are evidence that the cobble was firmly lithified and that the interstices were filled with cement before it was abraded, transported to this locality, and encrusted by the algal-foraminiferal colony.

The cobble contains scattered specimens of Endothyra sp., Millerella? sp., and Millerella marblensis? Thompson, 1942. A few specimens occur in the matrix, but most are nuclei of ooliths and therefore are poorly preserved. The Pitkin Limestone, which is very late Chester in age and underlies the Morrow in this region, is locally oolitic and contains foraminifers that are rather similar to those in this cobble. Though all the critical features needed for a positive identification of these foraminifers are not shown in these random sections, Morrow age is indicated with fair assurance. Thus, the oolite in the cobble is evidently of Kessler or pre-Kessler Morrow age.

The abraded surface of this nuclear cobble was closely studied to determine whether or not the quartz overgrowths of diagenetic stage 2 have positive relief over the adjacent carbonate of the ooliths and interstitial cement (figs. 15 and 16). The quartz seed grains generally have positive relief, but not as uniformly as might be anticipated. Some overgrowths have slightly positive relief, but as many or more have no differentiation. This indecisive evidence for antecedent age of the overgrowths is slightly complicated also by an extremely small amount of solution (apparently less than 0.005 $\mathrm{mm}$ ) that has occurred at the interface of the nucleus and the algal incrustation. It is not evident whether or not the very slight solvent action differentiated between the quartz seed, quartz overgrowths, and the adjacent carbonates.

The small relief between the quartz and carbonate areas is surprising. It is to be anticipated that the overgrowths are somewhat softer than the adjacent seed grain, but both are far more resistant to attrition than 
the carbonate. The overgrowths do not incorporate inclusions at their interface with the algal incrustations nor do they show any indications of having grown against the algal fossils such as are shown by the apophysis $c$ in figure 10, where crystal growth was stopped by an echinoderm ossicle. Both kinds of evidence suggest that the overgrowths antedated attrition and incrustation, but the evidence seems very ambiguous.

At this locality of the Kessler, colonies of Ottonosia in the basal conglomerate are replaced by microcrystalline silica, but adherent pieces of limestone, which have normal Kessler lithology and contain scattered ooliths with secondarily enlarged quartz nuclei, are not replaced. The following parts of the colony with the exotic nucleus of oolitic limestone are replaced by the microcrystalline silica: The carbonate of the encrusting colony, the carbonate that remained in the ooliths in the exotic cobble after the quartz nuclei had been enlarged, and the carbonate cement in the interstices of the ooliths in the exotic cobble. The replacement is incomplete. Prolonged boiling or immersion in normal hydrochloric acid leaves a soft, whitish, spongy, coherent residue of silica. The replacement is obviously selective of the algal-foraminiferal colonies.

The Kessler Limestone Member at localities f7083 and $\mathbf{f 1 2 8 1 5}$ in the Brentwood and Pitkin areas, Washington County, also contains fossils of Ottonosia and Osagia that are selectively replaced by spongy microcrystalline silica, which is somewhat limonitic. There too, no relationship is seen between the selective silicification of the fossils and the rather abundant examples of ooliths that show quartz-carbonate exchange.

The extent and characteristics of the selective microcrystalline silica replacement of the algal fossils in the Kessler have not been sufficiently studied to speculate on whether the replacement is connected with exhumation and weathering, decomposition of ash (whose presence has not been demonstrated), or some peculiar property of the carbonate in ottonosian colonies.

\section{SOURCE AND TRANSFER OF QUARTZ IN THE OVERGROWTHS}

\section{GEOLOGIC ENVIRONMENT}

Before considering the causes of the carbonate-silica exchange, the geologic setting is described to isolate the relevant factors.

The Morrow rocks in Washington County, Ark., and to some extent those in adjacent Oklahoma, are relatively undisturbed except for broad regional uplift. In the Morrow rocks of Washington County, where all but one of the localities herein described lie, fracturing is slight, and mineral veins are extremely scarce. The sedimentary load from Pennsylvanian to Cretaceous time is not directly determinable, but the rock columns of post-Morrow age in adjacent basins thin toward the Ozark platform, and no definite record of Permian and early Mesozoic deposition on or near this part of the Ozarks is known. It seems safe to speculate that the overburden did not exceed 4,500 feet and was more likely around 1,000-1,500 feet thick. The Baldwin coal, which lies half way between the Prairie Grove and Kessler Limestone Members, is of bituminous rank. Marine fossils in the Morrow are well preserved, and recrystallization of the limestone is of low order.

No regional chertification of a formation has occurred in the Ozark Plateaus since Early Mississippian time. Well-rounded pebbles and cobbles of chert, which were derived by erosion from the Mississippian Boone Formation, compose the larger part of a basal conglomerate at the base of the Batesville Sandstone of Chester age, on the banks of the Illinois River near Prairie Grove, Ark., near the center of the W1/2 sec. 8, T. 15 N., R. $31 \mathrm{~W}$. Northeast of Fayetteville, on the Stubblefield farm near the center of the $\mathrm{N} 1 / 2 \mathrm{NW}^{1 / 4} \mathrm{NE} 1 / 4$ sec. $36, \mathrm{~T} .17 \mathrm{~N} ., \mathrm{R} .30$ W., abundant angular to rounded pebbles or chert from the Boone are scattered through the Hindsville Limestone Member of the Batesville. Purdue and Miser (1916, p. 12) found chert and limestone detritus from the Boone in the Batesville Sandstone in the Eureka Springs quadrangle. Since Boone time, a second epoch of chertification (of as yet undetermined date) was recognized by Fowler, Lyden, Gregory, and Agar (1934) in the area of the Tri-State lead and zinc deposits, 70-100 miles north of the Morrow localities here described, but most of the younger chert deposition seems to be a product of exhumation and weathering between Boone and Pennsylvanian time (E. T. McKnight, oral commun., 1965). Specimens of Rayonnoceras and lenses of sandstone are silicified in the Fayetteville Shale on the north slope of Granny Peak near St. Joe, Ark. Silicified cephalopods also have been reported in rocks of approximately Fayetteville age in the northwest part of the Ouachita Mountains. More extensive silicification exists in the Fayetteville Shale east of Marshall, Ark.

The Morrow rocks of Washington County, Ark., had considerable protection by impervious shales from vertical circulation of solutions.

A hydrothermal or external source of silica solutions is opposed by the evidence at all but one of the oolite localities described above. This one exception is half a mile north of $\mathrm{f} 7083$, at the junction of Mill Creek and the West Fork of White River (the type locality of the Brentwood and Woolsey Members of the Bloyd Formation), where very small amounts of barite occur in the 
base of the Prairie Grove Member of the Hale. At one exposure, extremely minute amounts of pyrite and galena are scattered in the top of the Prairie Grove Member. Displacements in the rocks near here indicate small-scale faulting or large-scale creep. Residues from the top 15 feet of Prairie Grove limestone contain much secondarily enlarged sand. Some slightly etched sand and a very few examples of enlarged quartz sand nuclei also occur. It is not known whether the secondarily enlarged sand and the secondarily enlarged nuclei have a related origin. It is suspected that they represent different and unrelated diagenetic processes. A slight amount of mineralization from outside sources seems to have occurred at this locality, but this is unusual in the Morrow limestones in Washington County Ark.

\section{PROVENANCE, VOLCANIC ASH VERSUS SOLUTION ETCHING}

The clastic rocks in the Morrow Series of northwestern Arkansas and in the adjacent part of Oklahoma are composed for the most part, if not entirely, of maturely weathered, recycled detritus. So far as I know, the evidence indicates that the clastics came from the north, mostly from north and northeast of the Ozark Plateaus. Numerous thin sections of limestone, sandy limestone, and gravelly sandstone from the type area of the Morrow and adjacent formations reveal only very maturely weathered detritus, but a comprehensive petrologic study of these rocks, and particularly of interbedded shales, has not been made. Nevertheless, some features of the Morrow rocks in the type area and the known or inferred presence of volcanic ash in the middle and upper Paleozoic rocks of the Ouachita Mountains to the south have led to speculation on ash in the area here considered.

Secondarily enlarged sand without observed relations to oolites was observed in the Morrow rocks of Oklahoma by Moore (1947, text figs. 3-8) and in Arkansas by Henbest (1953, p. 1945 and 1951). Henbest (1945, p. $24 ; 1963$, p. 8$)$ suggested that the free silica may have been derived from volcanic ash, though no positive evidence of ash was known. No shards have been recognized. Fossils of silica-fixing organisms are unusually scarce. Chert is extremely rare. Two miniscule pockets of chert in the Prairie Grove Member of the Hale Formation, one on the southeast side of Bloyd Mountain in the headwaters of Mill Creek and the other on the west side of Kessler Mountain, both in Washington County, Ark., proved to be small thickets of sponge spicules. At some localities in the Kessler Limestone Member, Osagia and Ottonosia are replaced by spongy limonitic microcrystalline silica, as noted under diagenetic stage 3 . The possible relevance of the spongy silica as evidence for ash was not studied.
Evidence directly and indirectly suggestive of ash is available. In Fayetteville, Ark., beneath the LaFayette Street bridge over the south end of the St. Louis-San Francisco Railway cut, a local lens of chalcedony less than 1 foot thick is exposed on the east (downthrown) side of the Fayetteville fault. This chalcedony bed has a striking resemblance to chert seat rock of bentonite beds, and is thus considered possible evidence for ash. The bed lies near the common boundary of the Prairie Grove and Brentwood Members. The chalcedony consists of very fine angular matrix-supported quartz sand and of zones of minute sponge spicules, all with amorphous silica cement. I recognized no shards, and Clarence Ross of the U.S. Geological Survey recognized none in the samples he examined. The question of possible derivation from ash, however, is not regarded as closed.

Garner (1960; written commun., 1965), reported that though he has not directly identified volcanic debris in the Morrow and adjacent formations, he regards the presence of spheroidal weathering, "salt and pepper" textures in argillites, "bread-loaf" weathering, and several levels of abundant muscovite flakes as definite indications of volcanic detritus.

The seeming lack of positive evidence for ash in the Morrow of the type area and adjacent parts of Oklahoma cannot be taken as final for another reason. In the adjacent Ouachita geosyncline, volcanic rocks and fossils of silica-fixing organisms are being increasingly reported from the Paleozoic formations. Williams (1891, p. 375-376), Honess (1923, p. 108, 121-128, 179-183) and Miser and Purdue (1929, p. 62-64) have reported volcanic material in one or more of the following: Blaylock Sandstone (Silurian), Arkansas Novaculite (Devonian and Mississippian), and the lower part of the Stanley Shale (Mississippian). Henbest (1936) reported Radiolaria in Arkansas Novaculite from the Potato Hills, Okla., and sponge spicules and radiolarians(?) in the Bigfork Chert (Middle Ordovician) from the Strickland quarries, Stringtown, Oklahoma. (See also Hendricks and others, 1937, p. 10.) The discovery of volcanic rocks and silica-fixing organisms in the Arkansas Novaculite added another example to the list of associations of volcanism with deposits of diatomites, radiolarian cherts, and spiculites that were described by Taliaferro (1933). Goldstein and Hendricks (1953), seemingly unaware of the reports by Henbest and Taliaferro, published the results of an extensive study that extended the stratigraphic range and the number of occurrences of silica-fixing organisms in the Ouachita Mountains. Frezon and Schultz (1961) described sections of the Atoka Formation in the Ouachita Mountains that contain thin lithic zones which they interpreted as probably metabentonites. The lower part of the 
rocks that Frezon and Schultz included in the Atoka Formation may be of Morrow age.

Consideration of ash as the source of the free silica for the quartz overgrowths in the oolites and for the sand of Prairie Grove age in Oklahoma (Moore, 1947, text figs. $3-8$ ) is confronted by a possibility that free silica from diffused volcanics normally precipitates as chalcedony in its microcrystalline or crypotocrystalline (agate) forms, not as quartz overgrowths.

Though I have not attempted a systematic study of silicification as it affects carbonate fossil replacement, after seeing some thousands of thin sections of replacements of carbonate fossils by silica, I can recall none in which carbonate shells were replaced directly by quartz. The replacing silica is invariably cryptocrystalline, generally chalcedony but possibly opal. The examples for this generalization include replacements of fossils in cherty, in arkosic, and even in some ash-bearing units.

Quartz druse and anhedral quartz crystals commonly fill voids in the final stages of some replacements of limestone and included fossils by agate, but the deposition of druse is generally a final stage in a massive replacement, and the druse generally has no relation to the structure of the fossils. The residual chert from the Ordovician and Lower Mississippian rocks of the Ozark Plateaus contains cavities that were formed by leaching of nonsilicified fossils during weathering since exhumation. Such cavities may be filled or lined with druse and anhedral crystals of quartz, but the quartz did not directly replace the fossils in the examples studied.

The question of provenance of the silica was submitted to Brian Skinner of the U.S. Geological Survey, who reported as follows:

I have examined all the slides from $\mathrm{f} 886$ in detail and find no evidence of any volcanic debris, either ash or derivative mineral assemblages to be expected by devitrification or alteration of volcanic ashes. I am reasonably sure that this locality is either free of volcanic debris or contains only a negligible amount. Certainly the oolite beds do not contain sufficient volcanic debris to account for all the silica in the quartz growths.

Evidence for the presence of ash in the Morrow rocks of Washington County remains ambiguous. As will be shown, the question of ash content is probably irrelevant to the problem of carbonate-silica exchange in diagenetic stage 2 .

\section{ETCH PITS AND THE PROBLEM OF QUARTZ SOLUTION AND TRANSFER}

In the samples from the Gaylor Ferry locality (f886), the etch pits on the quartz sand grains from the matrix reflect the size and form of the calcite bodies that filled the pits rather than the crystal structure of the quartz. Except for grains of pure quartzite, which are rare, the quartz sand grains are clear crystalline quartz that include the usual variants of twinned and strained structures that are normally found in heterogeneous sand. The minute calcite bodies filling the etch pits are transparent to cloudy anhedral crystals.

Many etch pits are bounded by high, very thin membranes or fences seemingly composed of residual quartz (figs. 12-14). These fences marked the boundaries between secondarily enlarged calcite grains that filled the etch pits. The etch pits are microscopic and have somewhat undulating surfaces. They are unlike contact-pressure solution pits between quartz grains, which are characterized by rounded contours. They are also unlike stylolitic-interpenetration columns with intervening clay membranes between carbonate bodies. The usual marks of pressure-contact solution are missing from these etch pits.

It was attempted to compare the volume of the overgrowths with the volume of quartz removed by solution from grains in the matrix, but no unambiguous marks of the original size of the etched grains were found. The volume of quartz removed by etching varies from place to place in the area of a thin section. If the height of the fences between etch pits is taken as a minimum measure of the former size, a few grains had a volume loss as great as $1 / 5-1 / 3$ the original volume. The etched grains in the matrix that touched ooliths and that served as seed for overgrowths into ooliths (fig. 12) may bear some indication of their original shape and size by the necking on the seed grain at the base of the crystal that grew into the ooliths. No means is known for determining the possible presence originally of clay size grains of quartz, which should be the first to be dissolved and removed. The volume of silica derived by solution etching in the matrix and the increase of etching with nearness to ooliths with quartz sand nuclei are sufficiently great to give confidence that the overgrowths were derived entirely by etching.

In looking for causes of the quartz and carbonate exchange, the work of anaerobic bacteria and reactions connected with oil and gas come to mind, but direct evidence for their work or existence was not recognized. If the matrix and ooliths contained any organic matter, it probably would have lasted longer inside the more impervious ooliths than in interstitial space. As suggested by Brian Skinner (written commun., 1965), such would have contributed to the exchange by maintaining a long acid state inside the oolith and causing the solubility of quartz to be decreased and that of calcium carbonate to be increased. Though the presence of organic matter may have been a contributing factor in quartz deposition inside ooliths, it could hardly have been a major factor because secondary euhedral crystals of quartz are absent from the inside of calcitic shells, from magnesian calcite shells of Cornuspirinae, and from 
inside the algal-foraminiferal incrustations of Osagia. all of which probably contained some organic matter.

A consistent difference within the limestone did exist, however, in the aragonitic composition of ooliths and in the dominantly calcitic content of the matrix. Skinner further stated that "aragonite is the more reactive and calcite the less reactive of the two common forms of calcium carbonate."

A census of the kinds of situations wherein quartzcarbonate exchange took place and of the mineralogy of objects that were barriers to secondary quartz growth shows a uniform pattern. Wherever, in a microscopic realm of $2 \mathrm{~mm}$ or perhaps greater radius, quartz sand grains laid in contact with calcite and aragonite grains, the following occurred: At the quartz-calcite interfaces, quartz was solution etched and replaced by calcite, and at the quartz-aragonite interfaces, aragonite was replaced by euhedral extensions of the quartz grain, seemingly as a concurrent reaction.

The $\mathrm{pH}$ differential between calcite and aragonite in water solution and the alkalinity of each are both of low order. In terms of laboratory conditions, the effect of such a low $\mathrm{pH}$ difference on quartz solution has been regarded as immeasurable. Slowness of solution of quartz at low $\mathrm{pH}$ was repeatedly emphasized by Krauskopf (1959). Citing Okamoto, Okura, and Goto (1957), Krauskopf (1959, p. 9) stated that "All recent workers agree that the solubility of quartz at ordinary temperatures is essentially independent of $\mathrm{pH}$ for values below 9, but rises abruptly at higher values" and "In dilute alkali therefore-and this includes the range of alkalinity normally encountered in surface solutionssilica is no more soluble [in alkali] than in acid."

Two natural factors operated in these Morrow oolites, however, that cannot be represented in the laboratory. The factor of immense time at room temperature cannot be measured. The microscopic dimensions of the realm of reaction in the quartz-carbonate exchange would be difficult or impossible to duplicate.

Quartz overgrowths in sandstones and limestones are commonly attributed to the agency of circulating ground water. Without questioning the possible role of circulating ground water in forming quartz overgrowths in other situations, it is doubted that circulating water was an agent in the transfer of quartz in stage 2 of the Morrow oolites. Circulating water probably would have prevented the transfer by diluting and by dispersing the solutions below the threshold of reaction. This idea is suggested by the microscopically close position of overgrowths in ooliths and the areas of solution-etched quartz sand in the matrix. The examples at locality $\mathbf{f} 886$ of decreased etching of sand in matrix where the adjacent ooliths contained few quartz nuclei, and of greatest etching in the immediate proximity of ooliths containing quartz overgrowths, show both the microscopic limits of the silica-carbonate exchange and the necessity of static-water immersion. The silica transfer inside a single oolith at locality f862 (fig. 7) is a remarkable demonstration of the extreme minuteness of the realm of reaction and of the evident absence of the agency circulating water as the term "circulating" is usually construed.

Examples of replacement of silica by carbonate in sedimentary rocks have been noted from time to time in the literature. Reports of replacement of opaline sponge spicules frequently appear. Siever $(1959$, p. 69$)$ reported observations of carbonate replacements of chert and quartz. In a brief but significant paper, Walker (1957) listed the modes of natural frosting o quartz sand grains that had been previously described, and he proposed that "Still another cause of frosting, and one that has received little mention in the literature, is that caused by carbonate replacement of quartz along grain boundaries." Walker (1957, pl. 1, figs. 3-5) illustrated ooliths from the Oneota Dolomite (Lower Ordovician) at Madison, Wis., which appear to have had a similar history to that of some ooliths at f862 (fig. 7). The Morrow record supports Walker's general idea that the frosting is a product of reaction between the carbonate and quartz, but it also indicates that the reactions are more complicated than those he outlined.

Adams (1964, p. 1577) suggested that clay or carbonate cement acted as a barrier or protective coating against quartz overgrowth. The Morrow record would seem to call for a reinterpretation of the evidence in the situations with which he dealt. Siever $(1959$, p. 70) found little or no correlation between the occurrence of quartz and carbonate cementation in Pennsylvanian sandstones.

In his discussion of the inverse relation of clay and quartz cement, Siever (1959, p. 69-70) objected to the theory that lack of permeability in clay-filled interstitial space accounts for a low amount of quartz cementation. To the objection that Siever cited may be added to the evidence from the Morrow record that low permeability seems not to have been a factor in silica transfer. Though permeability of the matrix, but probably not of the ooliths, was probably high at the beginning of transfer of silica from the matrix to oolith interiors, the porosity of the matrix was probably low and may have been extremely low before the process was completed. Where great time is available, lack of porosity seems to be a negligible factor in microscopic diffusion.

It is proposed that the reactions of diagenetic stage 2 would not occur except in an environment of nearly static ground water, virtually the condition in a highly cemented matrix and more particulariy within an oolith 
(figs. 6 and 7). It is further proposed that the difference in reactivity between the calcium carbonates over a very great time, perhaps millions of years, was the active factor in the silica-carbonate exchange of diagenetic stage 2 . If reactivity between calcite and aragonite is the cause of the quartz-carbonate exchange in diagenetic stage 2 , the epoch of stage 2 is necessarily limited by the durability of aragonite, which is probably contingent on preservation of the connate sea water, an extremely variable condition. Exposure to fresh water is thought to hasten inversion to calcite.

Illing (1954, p. 48-49) found considerable inversion of aragonite to calcite in cays and isolated stacks of Pleistocene to Recent limestone in the Bahamas. A part of the calcite derived from aragonite had no preferred orientation. Graf and Lamar (1950, p. 2320) reported that no aragonite was detected in thin-section or X-raydiffraction analyses of oolithic limestones from the Fredonia Limestone Member of the Ste. Genevieve Limestone of Mississippian age in Illinois. The concentric and radial structure of the ooliths remains recognizable. Illing (1954, p. 40) determined that the accretionary layer in Recent ooliths from the Bahamas is aragonite. Though interspersed anhedral calcite grains in the accretionary layers of the ooliths are commonly assumed to be derived from original aragonite, the literature is vague on whether or not inversion normally destroys the concentric layers of radial, fibrous structure. In the Morrow oolites (figs. 2, 8, 9, and 11), the patterns are well preserved.

\section{DATE OF DIAGENETIC STAGES 1 AND 2}

Because the dates of diagenetic events are so critical in delineating the history and behavior of aquifers and oil and gas reservoirs, and because such historical data are surprisingly scarce, clues to the dates of diagenetic stages 1 and 2 are treated here with what may seem to border on preciosity.

The samples of oolitic limestone from f886 at the old Gaylor Ferry in Oklahoma and from f882 at Fayetteville, Ark., are crossed by a few microscopic fractures that are healed with sparry calcite. These fractures cut artifacts of diagenetic stages 1 and 2 , including several quartz overgrowths of stage 2 and their seed grains. In fresh outcrop samples of this limestone, fractures from hammer blows go around most of the quartz bodies. In my experience, natural fractures in limestone of similar composition and texture go around more quartz grains than happens in these samples. Though ambiguous, this evidence indicates that the limestone was under load when fractured and that the fractures occurred before exhumation. A large part of the exhumation and weathering of the rock formations now exposed in the Ozark Plateaus took place by Late
Cretaceous time, and the process has proceeded slowly since. The most that one can safely conclude concerning the age of these fractures is that they are pre-Recent and probably Cretaceous or older.

The meaning of the exotic cobble from the base of the Kessler in the dating of diagenetic stage 2, which was discussed previously, is extremely uncertain, but preKessler, Morrow time is suggested. This conclusion is supported by other, but similarly indefinite, evidence. Diagenetic stage 2 is earlier than stage 3. How much earlier is unknown. No connection or common cause between them is recognized. Diagenetic stage 3 appears to be associated with Cretaceous to Recent exhumation and weathering, but it could be older.

If, as seems to be demonstrated, the quartz-carbonate exchange in diagenetic stage 2 was caused by a combination of the alkalinity and the difference in reactivity between calcite and aragonite, the possible date of stage 2 is limited to the duration of aragonite. The duration of aragonite or its rate of inversion to calcite must be extremely varied in nature and dependent on the environment. The durability in some supposed aragonitic shells seems to be geologically brief, but no data on the durability of aragonite in ooliths were obtained for this paper. It is my opinion that diagenetic stages 1 and 2 and most of the cementation were completed before the end of the Morrow Epoch, but all the other evidence so far recognized is as indefinite as that listed above.

\section{MODIFIED METAL COATING FOR RESOLUTION OF MINUTE STRUCTURES}

Resolution of the etch pits in the minute grains of transparent quartz proved to be a difficult problem even when the quartz grains were mounted in Hyrax (refractive index 1.7), studied with a well-corrected apochromatic system, and illuminated in various ways (figs 12-14). Viewing the minute features of top surface of a transparent grain only $0.05 \mathrm{~mm}$ in diameter, for example, presents both the problem of optic artifacts of the top surface and the problem of those of the underlying surface $(0.05 \mathrm{~mm}$ or less distant) being simultaneously visible. Edward J. Dwornik of the U.S. Geological Survey kindly aided by vapor-coating several slides, some with silver and others with chromium. I chose silver because its surface can be darkened easily with a gas such as hydrogen sulfide, and it is easy to remove if desired. Silver can be removed without damage even to a carbonate fossil by a cutting reducer for photographic emulsions such as Farmer's solution.

Some of the slides were exposed to hydrogen sulfide gas in closed bottles until the mirror surface was perceptibly dulled. They were then mounted in Hyrax under cover glass and studied. This procedure worked much better than studying unmounted specimens. The 
silver and silver sulfide film defined the surface in submicroscopic detail as regards the visible spectrum. This method of coating avoided the problem of silver artifacts that is associated with coating by deposits from silver nitrate solution (Henbest, 1963, pl. 5). Mounting in Hyrax had the advantages of reducing the specular glare, increasing the surface contrast of the quartz grains, and increasing the depth of field at any given numerical aperature of objective.

\section{COLLECTION DATA}

All the collections are from the Morrow Series (Lower Pennsylvanian). The numbers refer to the catalog of the U.S. Geological Survey collections of Foraminifera.

\section{fry 1, Arkansas}

Unit.-Prairie Grove Member of the Hale Formation. Oolite limestone, at the top of the member. When the secondarily enlarged nuclei were first described from this collection (Henbest, 1945, p. 20), the oolite was identified as the Brentwood Limestone Member of the Bloyd Formation. The Prairie Grove and the Brentwood had not been differentiated at that time.

Location.-Washington County. Near top of massive limestone bench, east side of shallow hillside ravine on the east side of Mount Sequoyah (East Mountain on older maps) ; about 60 yards north of the center of the south boundary of the $\mathrm{SW} 1 / 4 \mathrm{SW} 1 / 4$ sec. $11, \mathrm{~T} .16 \mathrm{~N}$., R. $30 \mathrm{~W}$. Collected August 26, 1935, and October 29, 1936.

\section{f862, Arkansas}

Unit.-Prairie Grove Member of the Hale Formation. From oolitic limestone in the lowest $21 / 2$ feet of the massive 13- to 14-foot-thick crossbedded slightly reddish sandy limestone, which was quarried here. This massive bed is the topmost unit of the Prairie Grove.

Location.-Washington County. Old quarry on north side of Fayetteville-Goshen road at foot of northeast tip of Mount Sequoyah (East Mountain on older maps) ; northeastern part of Fayetteville; W1 $/ 2 \mathrm{SE} 1 / 4$, sec. 2. T. 16 N., R. 30 W. Collected October 26, 1936.

\section{f8\%1B, Arkansas}

Unit.-Kessler Limestone Member of the Bloyd Formation. Basal conglomerate of the member.

Location.-Washington County. Type locality of the Kessler Limestone Member. At west side of a shallow saddle near the north end of the highest part of the Kessler Mountain ridge, where erosion has removed the cap rock (Greenland Sandstone Member of the Atoka Formation) of the Mountain. This is near the center of the SE1/4, sec. 25 , T. 16 N., R. 31 W. Collected Novem- ber 3,1936 ; site revisited November 26,1947 with H. D. Miser.

\section{f886, Oklahoma}

Unit.-Bloyd Formation. (See stratigraphic description below)

Location.--Mayes County. About half way up south face of hill on northeast bank of the Neosho (Grand) River about a third of a mile upstream from the old Gaylor Ferry. Center of sec. 26, T. 18 N., R. 19 E. This is the same locality as USGS 1219, Carboniferous collections. Collected November 13, 1936.

Pennsylvanian:

Atoka Formation (basal bed) :

Pebble conglomerate, calcareous, ferruginous; gravel and pebbles abundant; fossiliferous; bench forming; USGS f888_............ $10+$

Morrow Series.

Bloyd Formation:

Covered............................

Limestone; bryozans; white powdery matrix, USGS f 887

Covered ...........................

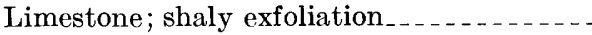

Covered ............................

Limestone, locally oolitic, medium gray to yellowish; Pachypora sp., USGS f886...

Mostly covered; some limestone with Pachypora $\mathrm{sp}_{\ldots} \ldots \ldots$

Hale Formation:

Limestone or calcareous sandstone, massive, cliff-forming, crinoidal, generall, crossbedded, medium to coarse; animal burrows locally prominent (Prairie Grove lithology)

Mississippian, Upper:

Limestone cobble conglomerate, gray, concretionary?; weathers white; no interstitial filling at outcrop;

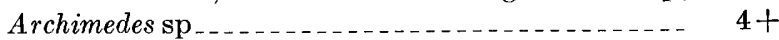

Shale, black fissile........ 3-4

Limestone; Diaphragmus sp. abundant__._._. - 9+ (top)

Covered by flood plain of Neosho River......... ?

This area is partly covered by the new artificial lake, but it is likely that the bed at $\mathbf{f} 886$ is still exposed. All fossil names in this description are field determinations at the time of collection (1936) and do not necessarily represent subsequent refinements in classification and nomenclature.

\section{f4831, Arkansas}

Unit.-Basal 10 feet of Prairie Grove Member of Hale Formation. Oolitic and crinoidal limestone bearing Pentremites angustus Mather, 1915, and scattered crystals of barite. Conglomeratic at base.

Location.-Washington County. Low cut on east side of U.S. Highway 71 southwest tip of Bloyd Mountain, roughly half a mile north along the highway from the junction of Mill Creek and the West Fork of the White River, and near the center of the NW1/4 SW1/4 
sec. 9, T. 14 N., R. 30 W. Collected December 11, 1943.

The erosional contact of the Prairie Grove on the Cane Hill Member is prominently displayed here. The basal conglomerate at the base of the Prairie Grove contains sparsely scattered cobbles from outside the region.

\section{fro83, Arkansas}

Unit.-Kessler Limestone Member of the Bloyd Formation.

Location.-Washington County. Near the center of the NE $1 / 4$ SE $1 / 4$ sec. 16 , T. 14 N., R. 30 W., about halfway up the mountain east of the Pitkin Post Office and the old Woolsey Station of the St. Louis-San Francisco Railway. Collected December 7, 1947.

The Kessler is characterized here, as commonly elsewhere, by an abundance of Osagia Twenhofel, 1919. Though the Osagia are replaced by limonitic, porous, spongy, microcrystalline silica from Recent(?) weathering, the "glittering sand" consists of secondarily enlarged quartz sand nuclei of ooliths. The two generations of silica seem to be unrelated.

\section{f12815, Arkansas}

\section{Unit.-Kessler Limestone Member of the Bloyd} Formation.

Location.-Washington County. Exposure in the terrace formed by the Kessler Limestone Member, oneeighth of a mile southwest of Brentwood station along the south side of the rural road leading up the mountain. Collected November 26, 1959.

Ooliths are sparsely scattered through this part of the Kessler. The quartz grain nuclei are secondarily enlarged. Quartz sand grains are rather abundant in the matrix but show little etching except at pressure points, particularly those with the echinoderm ossicles. The Osagia are selectively silicified by limonitic microgranular silica. The only secondarily enlarged quartz sand grains so far seen are those in ooliths.

\section{REFERENCES CITED}

Adams, W. L., 1964, Diagenetic aspects of lower Morrowan, Pennsylvanian, sandstones, northwestern Oklahoma: Am. Assoc. Petroleum Geologists Bull., v. 48, no. 9, p. 1568-1580, 6 figs., 2 pls.

Carozzi, A. V., 1960, Microscopic sedimentary petrography : New York, John Wiley \& Sons, 485 p., 88 figs.

DeFord, R. K., and Waldschmidt, W. A., 1946, Oölite and oölith : Am. Assoc. Petroleum Geologists Bull., v. 30, no. 9, p. 15871588.

Dunham, R. J., 1962, Classification of carbonate rocks according to depositional texture, in Ham, W. E., ed., Classification of carbonate rocks, a symposium: Am. Assoc. Petroleum Geologists Mem. 1, p. 108-121, pls. 1-7.

Fowler, G. M., Lyden, J. P., Gregory, F. E., and Agar, W. M., 1934, Chertification in the Tri-State (Oklahoma-KansasMissouri) mining district [with discussion] : Am. Inst. Min- ing Metall. Engineers Trans., v. 115, Mining Geology, p. 106-163, 32 figs., map.

Frezon, S. E., and Schultz, L. G., 1961, Possible bentonite beds in the Atoka Formation in Arkansas and Oklahoma, in Short papers in the geologic and hydrologic sciences: U.S. Geol. Survey Prof. Paper 424-C, p. C82-C84.

Garner, H. F., 1960, Upper Paleozoic stratigraphy and sedimentation of northern Arkansas [abs].: Geol. Soc. America Bull., v. 71, p. 1870.

Goldstein, August, Jr., and Hendricks, T. A., 1953, Siliceous sediments of Ouachita facies in Oklahoma: Geol. Soc. America Bull., v. 64, no. 4, p. $421-442,4$ pls., 2 figs.

Graf, D. L., and Lamar, J. E., 1950, Petrology of Fredonia oölite in southern Illinois: Am. Assoc. Petroleum Geologists Bull., v. 34, no. 11, p. 2318-2336, 19 figs.

Henbest, L. G., 1936, Radiolaria in Arkansas Novaculite, Caballos Novaculite, and Bigfork Chert: Jour. Paleontology, v. 10, no. 1 p. $76-78$.

1945, Unusual nuclei in oölites from the Morrow group near Fayetteville, Arkansas: Jour. Sed. Petrology, v. 15, no. 1 , p. $20-24$, figs. $1-6$.

1953, Morrow Group and lower Atoka Formation of Arkansas: Am. Assoc. Petroleum Geologists Bull., v. 37, no. 8, p. 1935-1953, 2 figs.

- 1962a, Type sections for the Morrow Series of Pennsylvanian age and adjacent beds, Washington County, Arkansas, in Short papers in geology, hydrology, and topography : U.S. Geol. Survey Prof. Paper 450-D, p. D38-D41.

1962b, New members of the Bloyd Formation of Pennsylvanian age, Washington County, Arkansas, in Short papers in geology, hydrology, and topography: U.S. Geol. Survey Prof. Paper 450-D, p. D42-D44.

1963, Biology, mineralogy, and diagenesis of some typical late Paleozoic sedentary Foraminifera and algal-foraminiferal colonies: Cushman Found. Foram. Research, Spec. Pub. 6. 44 p., 7 pls., 1 fig.

1965, Diagenetic phenomena in oölitic limestone, Morrow Series, Pennslyvanian, northwest Arkansas and northeast Oklahoma [abs.]: Geol. Soc. America Spec. Paper 82, p. 91.

Hendricks, T. A., Knechtel, M. M., and Bridge, Josiah, 1937, Geology of Black Knob Ridge, Oklahoma: Am. Assoc. Petroleum Geologists Bull., v. 21, no. 1, p. 1-29, 2 figs.

Honess, C. W., 1923, Geology of the southern Ouachita Mountains of Oklahoma; Part I, Stratigraphy, structure, and physiographic history, Part II, Geography and economic geology: Oklahoma Geol. Survey Bull. 32 ; pt. 1, 278 p., 92 pls., map ; pt. 2,76 p., 28 pls., text figs., map.

Illing, L. V., 1954, Bahaman calcareous sands: Am. Assoc. Petroleum Geologists Bull., v. 38, no. 1, p. 1-95, 9 pls., 13 figs.

Kholodov, V. N., 1960, On some criteria of the primary or secondary nature of bitumens: Akad. Nauk SSSR Izv. Ser. Geol. no. 4, p. 55-65, 7 figs. (English trans., pub. by Am. Geol. Inst.)

Krauskopf, K. B., 1959, The geochemistry of silica in sedimentary environments, in Ireland, H. A., ed., Silica in sediments, a symposium: Soc. Econ. Paleontologists and Mineralogists Spec. Pub. 7, p. 4-19, illus.

Miser, H. D., and Purdue, A. H., 1929, Geology of the De Queen and Caddo Gap quadrangles, Arkansas: U.S. Geol. Survey Bull. 808, 195 p., 18 pls., 9 figs., maps.

Moore, C. A., 1947, The Morrow Series of northeastern Oklahoma : Oklahoma Geol. Survey Bull. 66, 151 p., frontis. (2 pls.), 15 pls. and maps, 8 figs. 
Okamoto, Go ; Okura, Takeshi ; and Goto, Kasumi ; 1957, Properties of silica in water: Geochim. et Cosmochim. Acta., v. 12, no. 1-2, p. 123-132, illus.

Pettijohn, F. J., 1949, Sedimentary rocks: New York, Harper \& Bros., 526 p., 40 pls., 131 figs.

Plumley, E. J., Risley, G. A., Graves, R. W., Jr., and Kaley, M. E., 1962, Energy index for limestone interpretation and classification, in Ham, W. E., ed., Classification of carbonate rocks, a symposium: Am. Assoc. Petroleum Geologists Mem. 1, p. $85-107,5$ pls., 5 figs.

Purdue, A. H., and Miser, H. D., 1916, Description of the Eureka Springs and Harrison quadrangles [Arkansas-Missouri] : U.S. Geol. Survey Geol. Atlas, Folio 202, 4 maps, 9 pls., 13 figs., 1 table, 1 columnar section, 8 structure sections.

Robertson, E. C., 1955, Experimental study of the strength of rocks: Geol. Soc. America Bull., v. 66, no. 10, p. 1275-1314, 25 figs., 4 pls.

Siever, Raymond, 1959, Petrology and geochemistry of silica cementation in some Pennsylvanian sandstones, in Ireland, H. A., ed., Silica in sediments-a symposium: Soc. Econ. Paleontologists and Mineralogists Spec. Pub. 7, p. 55-79, 6 figs., 3 pls.

Taliaferro, N. L., 1933, The relation of volcanism to diatomaceous and associated siliceous sediments: California Univ. Dept. Geol. Sci. Bull., v. 23, no. 1, p. 1-56.

Walker, T. R., 1957, Frosting of quartz grains by carbonate replacement: Geol. Soc. America Bull., v. 68, no. 2, p. 267-268, pl. 1.

Williams, J. F., 1891, The igneous rocks of Arkansas : Arkansas Geol. Survey, Ann. Rept. for 1890 , v. 2, p. 1-391, 429-457, illus., maps. 




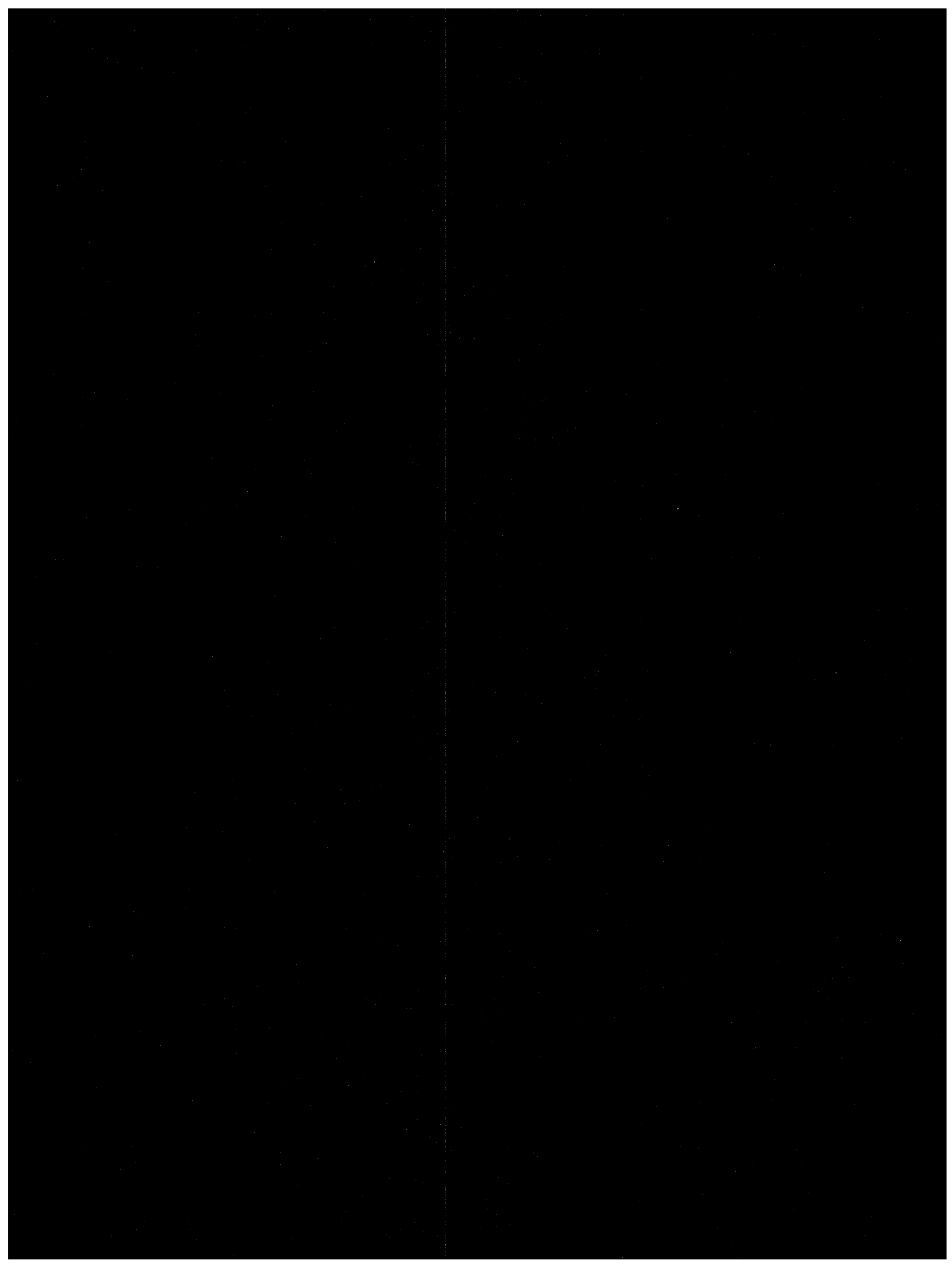




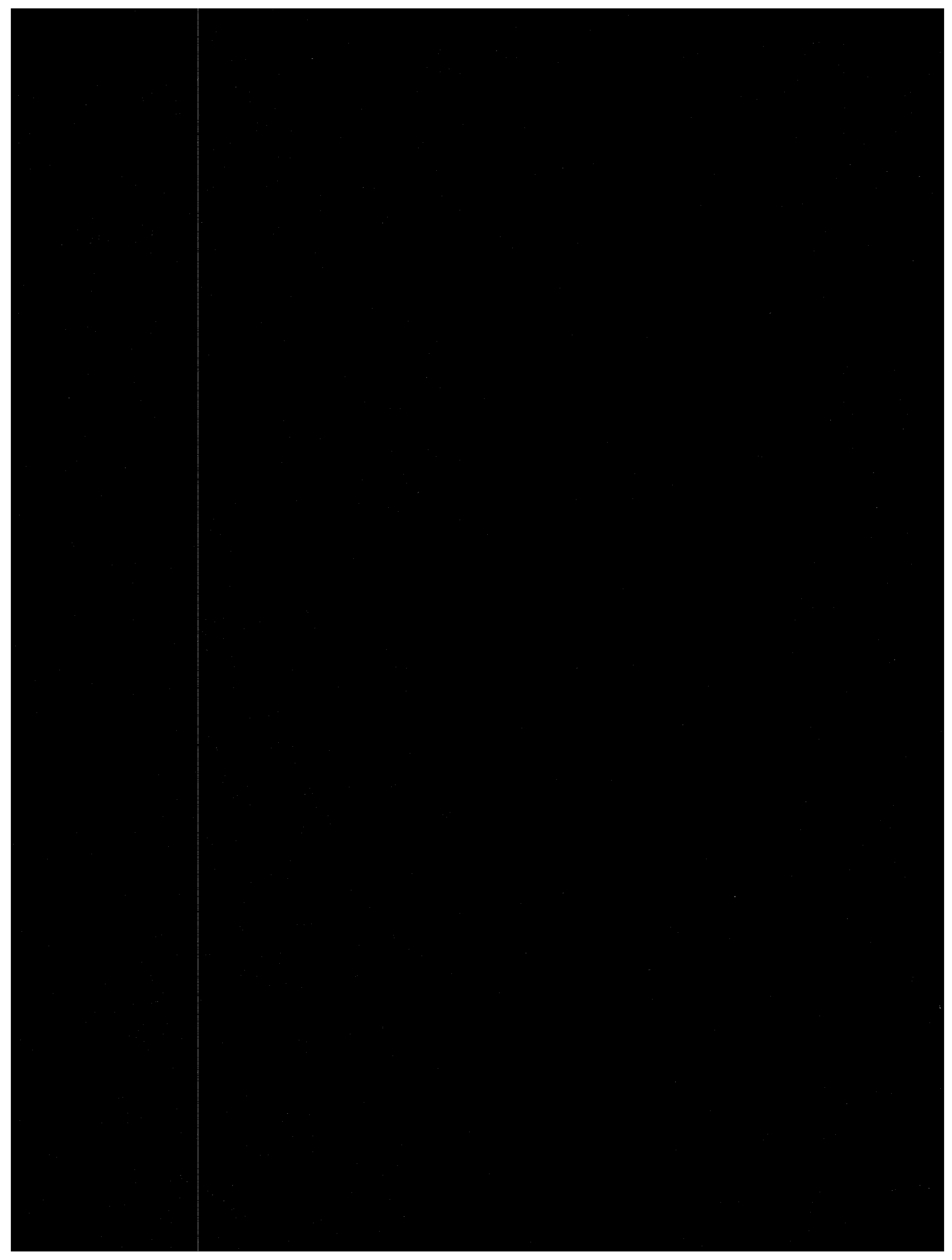

